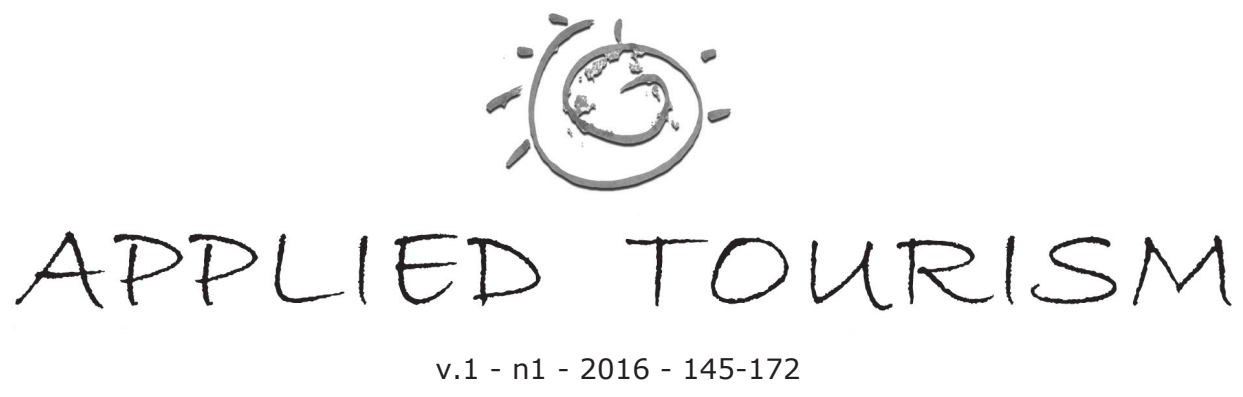

\title{
COMPETITIVIDADE NA DESTINAÇÃO TURÍSTICA: ANÁLISE DO DESEMPENHO REAL FRENTE AO DESEMPENHO PERCEBIDO PELOS GESTORES
}

\section{COMPETITIVENESS IN TOURIST DESTINATION: ANALYSIS OF REAL PERFORMANCE VS. PERCEIVED PERFORMANCE BY MANAGERS}

\begin{abstract}
Silvio Luiz Gonçalves Vianna - Doutor em Administração e Turismo - Universidade do Vale do Itajaí (UNIVALI). E-mail: slgvianna@ucs.br
\end{abstract}

Sara Joana Gadottr dos Anjos - Doutora em Engenharia de Produção/Gestão de Negócios Universidade Federal de Santa Catarina (UFSC). E-mail: sara@univali.br

Dr. Francisco Antonio dos Anjos - Doutor em Engenharia de Produção/Gestão Ambiental Universidade Federal de Santa Catarina (UFSC). E-mail: anjos@univali.br

Recebido/Received: 24 novembro/november 2014. Aprovação/Approval: 18 janeiro/january 2015.

\begin{abstract}
Resumo: O estudo da competitividade das destinações turísticas tornou-se freqüente junto à pesquisadores que buscam o entendimento de como esse fenômeno se desenvolve e porque algumas destinações alcançam resultados mais significativos do que outras que possuem atrativos mais interessantes. Grande parte das pesquisas tem por finalidade verificar o que uma destinação possui para torná-la mais desejada do que suas concorrentes, entendendo que a competitividade é um objetivo final a ser alcançado. Neste estudo tem-se por objetivo a análise do desempenho competitivo real de uma destinação em relação à percepção dos gestores que atuam no comando dos
\end{abstract}

Abstract: The study of the competitiveness of tourist destinations has become frequent among researchers; they seek to understand how this phenomenon develops and why some destinations reach more significant results than others that have more interesting attractions. Much of research is to verify which attributes make a destination more desirable than its competitors, understanding that competitiveness is an ultimate goal to be achieved. This study aims at analyzing the real competitive performance of a destination in relation to the perception of managers of tourism companies. To achieve this purpose the set of competitiveness indicators proposed by Dwyer and Kim (2003) was used as a 
empreendimentos existentes na área de turismo. Para alcançar este intento foi utilizado como base o conjunto de indicadores de competitividade propostos por Dwyer e Kim (2003) em seu modelo voltado à análise da competitividade de destinações turísticas. Como universo de pesquisa optou-se por um estudo de caso múltiplo envolvendo três municípios catarinenses, nos quais o turismo pode ser considerado como a atividade econômica de maior importância dentro da composição do PIB de serviços. A abordagem do estudo foi quantitativa, utilizando-se de uma pesquisa do tipo exploratória, que envolveu alguns aspectos descritivos para melhor analisar os indicadores envolvidos. Dentre as principais conclusões do trabalho é possível destacar a existência de correspondência entre o desempenho competitivo real da destinação e a percepção do mesmo pelos gestores entrevistados. Essa constatação permite que sejam definidas ações concretas por parte do poder público para melhorar o desempenho de uma destinação turística a partir de um levantamento feito junto aos gestores da iniciativa privada que mostre em que pontos os investimentos serão melhor aproveitados.

Palavras-chave: Turismo. Competitividade das Destinações Turísticas. Indicadores de Desempenho. Políticas Públicas.

\section{INTRODUÇÃO}

A primeira década do século XXI tem sido caracterizada por um conjunto de acontecimentos de abrangência global, que causaram impacto significativo no desenvolvimento do turismo. Entre as principais intercorrências que afetaram o turismo é possível destacar os ataques terroristas em larga escala (que tem se tornado frequentes), catástrofes naturais (como tsunamis, erupção de vulcões e furacões), crises políticas e a sucessão de crises econômicas, que causaram dificuldades para o desenvolvimento do turismo em todos os cantos do mundo.

Apesar de todas as dificuldades citadas, Blanke, Chiesa (2009) afirmam que o turismo continua sendo uma atividade estratégica para um grande número de países, muito em função de sua capacidade de influenciar de maneira positiva o crescimento e o desenvolvimento econômico. Seja por meio do incremento nos níveis de emprego e renda ou pela melhoria no balanço de pagamentos do país, fatores que basis; their model focuses on the analysis of the competitiveness of tourist destinations. As research universe we have chosen a multiple case study encompassing three municipalities of the state of Santa Catarina, in which tourism can be considered as the most important economic activity in the composition of GDP services. The approach of the study was quantitative, using an exploratory survey, involving some descriptive aspects to better analyze the indicators used. Among the main conclusions is the matching between the real competitive performance of the destination and the perception of it by the managers interviewed. This finding may help public entities to define concrete actions to improve the performance of a tourist destination, from a survey conducted with the managers of the private sector that shows the points at which investments will be better used.

Keywords: tourism, tourism destination competitiveness, competitiveness indicators, public policy.

\section{INTRODUCTION}

The first decade of this century has been characterized by a set of events of global range. They have significantly impacted the development of tourism. Among these is possible to highlight the terrorist attacks on a large scale (which has become common), natural disasters (such as tsunamis, volcanic eruptions and hurricanes), political crises and the succession of economic crises, which have caused difficulties for the development of tourism in every corner of the world.

Despite all the difficulties, Blanke and Chiesa (2009) argue that tourism is a strategic activity for a large number of countries, largely due to its ability to positively influence the growth and economic development; whether through the increase in the levels of employment and income or improving the balance of payments, factors that contribute to increasing prosperity and reducing poverty levels.

As a result of the above-reported situation, it can be seen that there is a trend toward increasing the number of establishments working in the tourism sector, a fact which, in turn, contributes to a fierce competition for a place in the market. Porter (1989) conducted a study whose objective was to understand the factors influencing the competitiveness of a nation. To ease the task, he developed an analytical model of competitiveness, which is now called "Porter Diamond". 
contribuem para o aumento da prosperidade e para a redução dos níveis de pobreza.

Como consequência da situação acima reportada, percebe-se que há uma tendência em relação ao aumento do número de estabelecimentos que surgem com intuito de atuar no segmento do turismo, fato este que por sua vez colabora para o incremento na disputa por um espaço no mercado. Porter (1989) desenvolveu um estudo cujo objetivo era o de compreender quais os fatores que influenciavam na capacidade competitiva de uma nação. Para auxiliá-lo nesta tarefa ele desenvolveu um modelo de análise da competitividade, que passou a ser chamado de "Diamante de Porter".

Neste modelo o autor (partindo do princípio que uma nação, que não necessariamente compete diretamente com outra nação) tenta compreender de que maneira um país pode desenvolver uma vantagem competitiva. Porter (1989) afirmava que o setor de serviços (segmento econômico em que se encaixa o turismo) pode ser apontado como um dos mais importantes para que um país tenha condições de incrementar sua competitividade.

Para entender como se desenvolve a competitividade dentro de uma destinação turística, Dwyer e Kim (2003) construíram um modelo de análise da competitividade que englobava tanto indicadores quantitativos (preço das acomodações, taxa de câmbio, preço das passagens aéreas, preço dos pacotes de viagem, renda per capta, taxa de crescimento econômico, entre outros), quanto qualitativos (nível de segurança do visitante na destinação, reconhecimento da importância da sustentabilidade no desenvolvimento do turismo, nível de cooperação entre as empresas dentro da destinação, receptividade dos residentes para com os turistas, entre outros). Ressalta-se que este foi o primeiro modelo que tornou explícita a visão de que a competitividade não é um objetivo final a ser alcançado e sim um objetivo intermediário. A competitividade, desta forma, deve conduzir a um objetivo maior, que está associado à melhoria em suas condições de vida dos residentes, por meio da viabilização de sua prosperidade socioeconômica.

O desejo de criação de um ranking de países (uma ferramenta que possibilitasse a realização de comparações entre o desempenho competitivo de diferentes localidades, visando dar condições para que uma determinada destinação possa almejar
In this model the author, - assuming that a nation does not necessarily compete directly with other nation-, tries to understand how a country can develop a competitive advantage. Porter (1989) stated that the service sector (economic segment that includes tourism) can be seen as one of the most important for a country to increase its competitiveness.

To understand how the competitiveness develops within a tourist destination, Dwyer and Kim (2003) built an analytical model of competitiveness that included quantitative (price of accommodation, exchange rate, price of air tickets, the price of travel packages, income per capita, economic growth rate, etc.) and qualitative indicators (visitor safety level in the destination, recognition of the importance of sustainability in tourism development, level of cooperation between companies within the destination, hospitality of residents toward tourists, etc. ). It is emphasized that this was the first model that made explicit the perspective that competitiveness is not an end goal to be achieved but an intermediate goal. The competitiveness thus, should lead to a higher goal, which is associated with the improvement of residents' living conditions, facilitating their social and economic prosperity.

The desire to create a ranking of countries (a tool that would allow comparisons between competitive performances of different locations, permitting that a given destination improved its supply conditions equating or even surpassing the performance of other destinations) made Blanke, Chiesa and Herrera (2009) present a third version of the study by the WTTC (World Travel \& Tourism Council) aimed at creating this generic index of competitiveness worldwide, whose name has become Tourism Competitiveness Index (LCI).

By analyzing the competitiveness of a destination there are two distinct aspects that have been worked separately: the competitiveness perceived by managers of tourism enterprises and the effective competitiveness of a destination that has been measured using a set of indicators chosen in different ways by authors such as: Crouch and Ritchie (1995, 1999), Heath (2002), Ritchie and Crouch (2003), Dwyer and Kim (2003) and Blanke, Chiesa and Herrera (2009).

Based on the above premise, the question of research that led to this study arises: the effective competitive performance of a destination, whose main economic activity is tourism, corresponds to the competitive 
a melhoria em suas condições de oferta, de tal modo a alcançar o desempenho igual ou superior ao de destinações em melhor situação) fez com que Blanke, Chiesa e Herrera (2009) apresentassem uma terceira versão do estudo elaborado pelo WTTC (World Travel \& Tourism Council) voltado à criação desse índice genérico de competitividade em âmbito mundial, cuja denominação passou a ser Índice de Competitividade do Turismo (ICT).

Ao analisar a competitividade de uma destinação nota-se que existem duas informações distintas e que têm sido trabalhadas de maneira isolada: a competitividade percebida pelos gestores ligados a empreendimentos na área de turismo e a efetiva competitividade de uma destinação que tem sido mensurada por meio de um conjunto de indicadores de competitividade escolhidos de diferentes maneiras por autores como: Crouch e Ritchie (1999), Heath (2002), Ritchie e Crouch (2003), Dwyer e Kim (2003) e Blanke, Chiesa e Herrera (2009).

Partindo da premissa acima exposta surge a questão de pesquisa que deu origem ao presente estudo: $O$ desempenho competitivo efetivo de uma destinação cuja principal atividade econômica seja o turismo é correspondente ao desempenho competitivo percebido pelos gestores dos empreendimentos ligados a essa área?

Para encontrar respostas para o problema de pesquisa apresentado foi desenvolvido um estudo no Estado de Santa Catarina. O universo de pesquisa envolveu os municípios de: Balneário Camboriú, Bombinhas e Garopaba, os quais segundo informações coletadas junto à Santur (2008) têm no setor de serviços o segmento mais importante de seu PIB (Produto Interno Bruto), representando mais de $50 \%$ do valor total. Além disso, utilizou-se como critério para escolha dos municípios, o fato de que a receita estimada do turismo correspondesse a mais de $50 \%$ do valor deste segmento.

\section{AS DESTINAÇÕES TURÍSTICAS}

Uma destinação turística pode ser considerada como sendo um local geográfico, para o qual devem se dirigir os turistas, com o objetivo de aproveitar sua viagem. O caminho percorrido entre a origem e o destino já está incluído como fazendo parte da experiência turística, e o local para onde se desloca o turista (o destino turístico) pode ser chamado de diferentes formas, como: núcleo turístico performance perceived by managers of businesses related to this area?

To find answers to the research problem presented, a study was developed in the state of Santa Catarina. The research base were the municipalities of: Camboriú, Bombinhas and Garopaba which, according to information collected by Santur (2008), have in the services sector the most important segment of its GDP (Gross Domestic Product), representing more than $50 \%$ of the total. Further, it was used as a criterion for the choice of cities, the fact that the estimated tourism revenue corresponds to more than $50 \%$ of this segment.

\section{THE TOURIST DESTINATION}

Tourist destination can be considered as a geographic location, to which tourists go, in order to enjoy their trip. The path between the source and the destination is already included as part of the tourist experience, and the place to which the tourist is moving (tourist destination) can be called in different ways, such as tourist center (in the case of a theme park); tourist area (such as the Sierra Santa Catarina); tourist municipality (such as Balneário Camboriú); or region (such as Florianópolis) (OMT, 2001).

Buhalis (2000) argues that a tourist destination is an amalgam of tourism products, which give the tourist the feeling of an integrated experience. To the author, each consumer has a peculiar and particular way of perceiving a destination, thus making it a subjective question that will depend on the travel itinerary. For example, London could be considered a tourist destination for a German business traveler. As for a Japanese vacation traveler, which has a tourist travel package with two weeks and whose itinerary encompasses six different countries, Europe will be considered as his tourist destination.

Political and geographical barriers, artificially created, are often used as a way to define a destination. However, such limits do not take into account consumers' wishes and needs, let alone the functions that interfere with the development of the tourism sector. From this perspective, Buhalis (2000) points out that a destination can be understood as a mix of products become available under a particular name in a specific location and that will be consumed on-site, impossible to store or take somewhere else. 
(caso trate-se de um parque temático); zona turística (como é o caso da Serra Catarinense); município turístico (tal como Balneário Camboriú); ou região (como ocorre com a Grande Florianópolis) (OMT, 2001).

Buhalis (2000) afirma que uma destinação turística é um amálgama de produtos turísticos, os quais proporcionam aos turistas a sensação de uma experiência integrada. Para o autor cada consumidor possui uma maneira peculiar e particular de perceber como se constitui uma destinação, tornando-se, portanto, cada vez mais uma questão subjetiva, que dependerá de seu roteiro de viagens. Desta forma, Londres será considerada como sendo uma destinação turística para um viajante de negócios Alemão. Já para um viajante Japonês em férias, que possui um pacote de viagens com duas semanas de duração e cujo roteiro se estende por seis diferentes países, a Europa passará a ser considerada como sua destinação turística.

As barreiras políticas e geográficas, artificialmente criadas, são, com frequência, utilizadas como forma de delimitação de uma destinação. Contudo, tais delimitações não levam em consideração desejos e necessidades dos consumidores e muito menos as funções que interferem no desenvolvimento do setor de turismo. Dentro desta perspectiva, Buhalis (2000) destaca que uma destinação pode ser entendida como o mix de produtos que passam a ser oferecidos sob uma determinada denominação num local específico e que passarão a ser consumidos no próprio local, não havendo condições para que sejam armazenados ou sequer transportados para algum outro lugar.

Uma das maiores dificuldades encontradas para a divulgação de uma destinação turística, de acordo com os estudos de Crouch (2007) está associada ao fato de que esta se encontra relacionada à experiência a ser vivida pelo turista naquela localidade. $E$, portanto, não apresenta elementos que possam constituí-la em um produto turístico convencional, uma vez que o efeito a ser percebido pelo visitante não está restrito à estrutura existente para recebêlo, mas sim ao resultado da ação conjunta do grupo de empresas envolvido na prestação do serviço, de maneira direta ou indireta.

O presente estudo considerará a destinação turística, de maneira análoga ao que feito nos estudos de Buhalis (2000) e Mota, Vianna e Anjos (2013) e corresponde a uma região definida geograficamente
A major difficulty for the promotion of a tourist destination, according to the studies of Crouch (2007), is the fact that it is related to the experience to be lived by the tourist in that area. And, therefore, it does not present elements which can transform it as a conventional tourism product; the effect to be noticed by visitors is not restricted to the existing structure to receive them, but is also the result of the combined action of the set of companies involved in providing the service, directly or indirectly.

This study will consider the tourist destination in the same way as Buhalis (2000) and Mota, Vianna and Anjos (2013) i.e., corresponding to a region defined geographically which can be considered as an autonomous unit, which has centralized management which, in the specific case of this work, correspond to the boundaries of a municipality. Thus making possible the evaluation of Destination Management Organization (DMO), and creating the conditions to discuss its planning and how the policies, guidelines and strategies are defined, aimed at understanding and monitoring the development of activities related to the tourism sector in those municipalities.

\section{COMPETITIVENESS}

The first studies on competitiveness were aimed at the business sector. In the 1980s, Porter (1986) developed a model (which became known as "the Porter's five forces model") by which the profitability of a given economic sector could be understood on the basis of the existing power relations between five distinct groups (buyers, suppliers, competitors, substitute products or services and new entrants). He found that when a certain group wielded greater power over others, this limited the percentage gains that could be achieved within that economic sector. It is noteworthy that Porter's academic background is in Economics and his biggest influence is the paradigm of Industrial Organization (IO).

In order to understand how competitiveness can extrapolate business and reach a global scope, involving the dispute between nations, Porter (1989) goes on to review aspects regarding the various actors and entities involved; in addition to the corresponding complexity of values, policies and guidelines related to the public entities' role in any of the 
que pode ser considerada como sendo uma unidade autônoma, a qual possui gestão centralizada, o que no caso específico deste trabalho corresponderá às fronteiras de um município. Desta forma será viabilizada a avaliação da Gestão Organizacional da Destinação, também conhecida como DMO (Destination Management Organisation), além de criar as condições para que se discuta o seu planejamento e a maneira como são definidas suas políticas, diretrizes e estratégias, visando a compreensão e o acompanhamento do desenvolvimento das atividades ligadas ao setor turístico naqueles municípios.

\section{A COMPETITIVIDADE}

Os primeiros estudos sobre competitividade restringiam-se ao âmbito empresarial. Na década de 1980, Porter (1986) desenvolveu um modelo (que ficou conhecido como "o modelo das cinco forças de Porter") por meio do qual se verificava que a lucratividade de determinado setor econômico poderia ser entendida com base nas relações de poder existentes entre cinco grupos distintos (compradores, fornecedores, concorrentes, produtos e ou serviços substitutos e novos entrantes). $O$ autor constatou que quando um determinado grupo exercia maior poder sobre os demais, este limitava o percentual de ganhos que poderia ser obtido dentro daquele setor econômico. É possível entender melhor a visão de Porter ao apurar que sua formação deu-se na área da economia e o paradigma da Organização Industrial (OI) sua maior influência.

Com o intuito de compreender como a competitividade pode extrapolar o âmbito empresarial e alcançar uma abrangência global, que envolve a disputa entre nações, Porter (1989) passa a analisar os aspectos que envolvem os diversos atores e entidades envolvidos, além da correspondente complexidade de valores, políticas e diretrizes inerentes à atuação do poder público em qualquer dos três níveis (nacional, estadual ou municipal).

Numa outra linha de pesquisa surgem os estudos Peteraf (1983), Wernerfelt (1984) e Barney (1991) que deram origem a uma nova teoria, que ficou conhecida como RBV (Resource Based View) ou VBR (Visão Baseada em Recursos). Nesta nova corrente de pensamento observa-se que para uma determinada empresa alcançar lucratividade three levels (national, state or municipal).

Another line of research appears with the studies of Peteraf (1983), Wernerfelt (1984) and Barney (1991) giving rise to a new theory, known as Resource Based View (RBS). For a given company to achieve profitability superior to that of its competitors, by obtaining competitive advantages, it needs to find among its products or services those who have four key features: differentiated value that customers accept to pay for it; rarity; difficulty of imitation; and difficulty of replacement. This type of product or service will enable companies, when appropriate strategies of management are put forward, to achieve higher returns than direct competitors and also to reach interesting returns relatively to their investments.

Due to the constant changes in the business environment, Teece, Pisano and Shuen (1997) developed the concept of dynamic capabilities when they verified that the presence or existence of a specific set of valuable resources, rare, difficult to emulate or replace was not enough for a particular firm to achieve a superior performance, as was stated by the proponents of RBV. The authors found that companies should develop internal capabilities to adjust to a dynamic environment; and, by doing so, achieve superior performance and a prominent position in relation to their immediate competitors.

In the second half of the 1990s, the discussion on competitiveness returned to the business world with the studies of Wernerfelt (1984), Barney (1991) and Teece, Pisano and Shuen (1997) focusing in that environment. Aiming at expanding the scope of the issue, Ghemawat (2000) brought to the discussion the concepts of dynamic competitiveness and he started working with business units, which went beyond the boundaries of a single corporation and, in some cases, went beyond a nation, encompassing multiple structures in different countries.

Analyzing the implications and assumptions of the theories RBV and dynamic capabilities, it is noted that both are very close to the reality of the tourism sector. Therefore, they constitute the epistemological frame upon which the theoretical tools of this study are based.

To Newall (1992), competitiveness is a very complex concept and its scope goes beyond the strictly economic sphere. It is linked to the production of goods and services 
superior à de seus concorrentes, por meio da obtenção de vantagens competitivas, ela precisa encontrar entre seus produtos ou serviços aqueles que possuam quatro características fundamentais: valor diferenciado que os clientes aceitem pagar por ele; raridade; dificuldade de imitação; e dificuldade de substituição. Este tipo de produto ou serviço possibilitará que as empresas, ao utilizarem-se de estratégias adequadas em sua gestão, obtenham retornos maiores frente aos seus concorrentes diretos além alcançarem retornos mais interessantes em relação aos seus investimentos.

Devido às constantes mudanças que ocorrem no ambiente empresarial, Teece, Pisano e Shuen (1997) desenvolveram o conceito de capacidades dinâmicas, ao constatar que não bastava a uma determinada empresa a presença ou existência de um conjunto específico de recursos valioso, raros, de difícil imitação e de difícil substituição, para conseguir um desempenho superior, como era afirmado pelos defensores da RBV. Os autores verificaram que se fazia necessário o desenvolvimento das capacidades internas da organização, visando adequá-la às constantes variações do ambiente, que é dinâmico, e exige ajustes constantes nos caminhos das empresas que desejarem alcançar desempenho superior, que possibilite atingir uma posição de destaque em relação aos seus concorrentes imediatos.

Na segunda metade da década de 1990, pode-se perceber que a discussão sobre competitividade havia voltado a ficar restrita ao ambiente empresarial, uma vez que os estudos de Wernerfelt (1984), Barney (1991) e Teece, Pisano e Shuen (1997) concentramse neste tipo de ambiente. Com o intuito de expandir o campo de visão com relação a este assunto, Ghemawat (2000) buscou ampliar a discussão envolvendo os conceitos da competitividade dinâmica, passando a trabalhar com as unidades de negócio, as quais iam além das fronteiras de uma única corporação e em alguns casos, iam além de uma nação, englobando estruturas múltiplas em diferentes países.

Analisando as implicações e os pressupostos tanto da teoria da visão baseada em recursos (RBV), quanto da teoria das capacidades dinâmicas observa-se que ambas encontram-se muito próximas da realidade do setor turístico. Isto faz com que elas sejam as escolhidas como bases epistemológicas of better quality which tend to be successfully sold to consumers, either domestically or in foreign markets. This may contribute to create high-paying jobs and generate resources, which will contribute to the consolidation of public services whose fundamental principle is to meet the needs of the poorest populations.

In his study on Slovenia's competitiveness (whilst tourist destination), Omerzel (2008, p.168) makes a statement in relation to this concept that deserves highlight: "[...] to be competitive, any organization must provide products and services that meet the unlimited wants of modern consumers. For such products and services, consumers or customers will be willing to pay a fair price". The researcher focus on the needs of customers and consumers, and also on the amount they are willing to spend to be able to acquire or make use of these goods and services.

Vianna (2011, p 65-66) in his study on the subject sought to integrate the different views on the subject, and put forward a definition of competitiveness encompassing all aspects explored here:

[...] The ability of companies to provide goods and services that meet the needs of consumers for a fair price and which enables the company operating in the market, to gain financial returns consistent with the interests of shareholders and investors, and to contribute to environmental preservation and to improve the population's quality of life.

This definition fits in perfectly to the inherent microenvironment conditions; i.e., the locus where the competition between different companies and organizations in the market happens. However, this study focus in the tourist destination, and so the discussion must be taken to this new level, expanding the scope, which will be held in the next section.

\section{THE COMPETITIVENESS OF TOURIST DESTINATIONS}

The generation of competitive advantages in a tourist destination was the focus of Crouch and Ritchie's (1999) research. They discussed the existing comparative advantages and also the aspects related to the generation of them. To the authors, the comparative advantages can be divided into two different types: inherited advantages (human resources, physical resources, cultural resources, 
mais adequadas para orientar a construção do ferramental teórico que servirá de base para a elaboração do presente estudo.

Para Newall (1992) a competitividade pode ser considerada com um conceito bastante complexo e cuja abrangência vai muito além dos aspectos eminentemente econômicos. Pois, encontra-se vinculada à produção de bens e serviços de melhor qualidade e que tendem a ser vendidos com sucesso aos consumidores, seja no mercado interno ou no mercado externo. Tal situação pode contribuir para a geração de empregos bem remunerados, que irão facilitar a geração de recursos, o que tornará viável a consolidação de serviços públicos que tenham por princípio fundamental o atendimento das necessidades das populações mais carentes.

Em seu estudo sobre a competitividade da Eslovênia (entendendo-a enquanto destinação turística), Omerzel (2008, p.168) faz uma afirmação em relação a esse conceito que merece ser destacada: "[...] para ser competitiva, qualquer organização deve prover produtos e serviços, que satisfaçam os desejos ilimitados dos consumidores modernos. Por tais produtos e serviços, os consumidores ou clientes, estarão dispostos a pagar um preço justo". Como é possível observar nesta citação a pesquisadora preocupa-se com as necessidades dos clientes ou consumidores e também com o montante que estes se disporiam a desembolsar para ter condições de adquirir ou de usufruir destes bens e serviços.

Vianna (2011, p. 65-66) em seu estudo sobre o assunto buscou integrar as diversas visões sobre o tema, e construiu uma definição de competitividade que englobasse todos os aspectos até aqui explorados:

[...] a capacidade das empresas em prover bens e serviços que satisfaçam as necessidades dos consumidores, por um preço justo e que permitam à empresa sua manutenção no mercado, obtendo retornos financeiros compatíveis com os interesses dos acionistas e investidores, além de contribuir para a preservação ambiental e para a melhoria da qualidade de vida da população.

Tal definição condiz perfeitamente às condições inerentes ao microambiente, que é lócus onde se processa a competição entre as diversas empresas e organizações existentes no mercado. Contudo, este estudo está focado no âmbito das destinações turísticas, e assim knowledge and financial resources) and the created advantages (tourism infrastructure and superstructure). On the other hand, competitive advantages can be those related to adequate management of existing resources in the destination, aforementioned in the comparative advantages, making them the success factor that contributes to the differentiation of the destination.

Having a set of competitive advantages may not be enough for a certain place, because as shown by studies developed by Kim and Dwyer (2003) it gives a false sense of security. If the advantages are not sustainable the benefits will be temporary and with shortterm return. However, such a situation can cause damage to the entire destination, since its competitive advantage might be imitated or replaced by one of its direct competitors. In order to achieve this kind of sustainability, the authors state that it should go beyond economic aspects, and include ecological, social, cultural and political sustainability.

At the end of the first decade of this century, Tsai, Song and Wong (2009) found that a destination to be considered competitive must have both the ability to attract and meet the needs of potential tourists, thus obtaining direct and indirect results. For, as the authors say, all the stakeholders may benefit from a leading competitive position. It is still interesting to note that the authors found that the competitiveness, according to the studies by Dwyer and Kim (2003), should not be considered an end in itself, since the main purpose is to lead to a higher goal, which is associated with the improvement of living conditions of the inhabitants of that destination.

In view of the various definitions of competitiveness of tourist destinations revised up to this point of the study, it was chosen the one by Vianna (2011, p.70), which better guides on the most appropriate path leading to the generation of sustainable competitive advantages. In addition, it is in line with the ontological and epistemological principles upon which this study is based.

The competitiveness of a destination is its ability to offer integrated tourism products and services that meet the needs of tourists, at a fair price, in order to ensure the sustainability of the ventures, through adequate returns to investors and enabling the preservation of environment and improving the quality of life for residents. 
precisa levar a discussão para este novo patamar, ampliando o escopo de visão, o que será realizado no tópico a seguir.

\section{A COMPETITIVIDADE DAS DESTINAÇÕES TURÍSTICAS}

A geração de vantagens competitivas em uma destinação turística foi o foco das pesquisas de Crouch e Ritchie (1999), que constataram a necessidade de discutir desde os aspectos ligados às vantagens comparativas existentes, quanto àqueles associados à geração de vantagens competitivas. Para os autores as vantagens comparativas podem ser divididas em dois tipos diferentes: as vantagens herdadas (recursos humanos, recursos físicos, recursos culturais, conhecimentos e recursos financeiros) e as vantagens criadas (infraestrutura e superestrutura do turismo). Por outro lado, as vantagens competitivas podem ser consideradas como sendo aquelas ligadas à adequada gestão dos recursos existentes na destinação e que foram citados nas vantagens comparativas, tornando-os fatores de sucesso que contribuam para a criação de diferenciais na destinação.

Não basta a uma determinada localidade obter um determinado conjunto de vantagens competitivas, pois como demonstram os estudos desenvolvidos por Kim e Dwyer (2003) isso dá uma falsa sensação de segurança. Pois, caso a mesma não seja sustentável obter-se-á apenas um benefício temporário e que trará retorno no curto prazo. Contudo, tal situação pode fazer com que toda a destinação venha a sofrer grande impacto, uma vez que sua vantagem competitividade possa vir a ser imitada ou substituída por um de seus competidores diretos. Para que se alcance tal tipo de sustentabilidade, os autores afirmam que a mesma não deve ficar restrita aos aspectos econômicos, mas incluir também as características associadas à sustentabilidade ecológica, social, cultural e política.

No final da primeira década do século XXI, Tsai, Song e Wong (2009) verificaram em suas pesquisas que para uma destinação ser considerada competitiva, a mesma precisa possuir a capacidade tanto de atrair, como de satisfazer os potenciais turistas, o que conduziria à obtenção de resultados diretos e indiretos desta situação. Pois, como afirmam os autores, todos os envolvidos podem ser alcançados pelos benefícios oriundos de uma posição competitiva de destaque.
The above definition seeks to be quite comprehensive and involve both the economic aspects, that are the focus of most researchers, and the social, cultural and human aspects that tend to ensure the sustainability of activities.

\section{METHODOLOGICAL PROCEDURES}

This research is of an exploratory nature, with a descriptive bias in order to obtain an overview of the phenomenon. It is the most appropriate method for studying topics that have been little explored and about which there is a certain difficulty to formulate specific hypothesis.

A quantitative approach was chosen, since the main purpose is to verify the correspondence between the results obtained through the analysis of two distinct measures of competitiveness: the one perceived by managers and the one effectively measured, using performance indicators of the destination.

In terms of research strategy, the author has chosen the realization of a multi-case study, by means of which sought to find evidence that according to studies by Yin (2010) could lead to the confirmation of the specific aspects that determine the occurrence of the phenomenon.

To achieve the proposed objectives, Dencker (2001) states that variables must be chosen based on the theoretical framework and must help identifying the most important features of the phenomenon under study.

Table 1 shows the set of variables used to evaluate the perception of managers regarding the competitive performance of their tourist attractions when compared with the average performance of tourism in the state of Santa Catarina. Vianna (2011) used as theoretical framework for the construction of this set of variables and indicators the works by Porter (1989), Esser et al. (1996), Heat (2002), Ritchie and Crouch (2003), Dwyer and Kim (2003) and Blanke, Chiesa and Herrera (2009). Subsequently the whole set was revised, discussed and expanded by the study group of Planning and Management of the Tourism Space of UNIVALI (University of Vale do Itajaí (Table 1 ).

We opted for broader indicators that would enable further development, through specific studies, aimed at explain in detail the reasons that led managers to understand the 
Ainda é interessante destacar que os autores constataram que a competitividade, de acordo com os estudos de Dwyer e Kim (2003), não deve ser considerada um fim em si, uma vez que o intuito principal é o de conduzir a um objetivo superior, que se encontra associado à melhoria das condições de vida dos moradores daquela destinação.

Tendo em vista as diversas definições sobre competitividade das destinações turísticas revisadas até este ponto do estudo, optouse pela de Vianna (2011, p.70), que orienta melhor quanto ao caminho mais adequado à geração de vantagens competitivas, que possam ser sustentadas. Além de estar em consonância com os princípios ontológicos e epistemológicos sob os quais está pautado o presente estudo.

\begin{abstract}
Competitividade da Destinação é a capacidade da mesma em oferecer produtos e serviços turísticos integrados, que atendam as necessidades dos turistas, a um preço justo, de forma a garantir a perenidade dos empreendimentos, por meio de retornos adequados aos investidores, e possibilite a preservação do meio-ambiente e a melhoria da qualidade de vida dos residentes.
\end{abstract}

A definição acima busca ser bastante abrangente e envolver tanto os aspectos econômicos que são o foco da maioria dos pesquisadores, quanto os aspectos sociais, culturais e humanos, que tendem a garantir a sustentabilidade das atividades desenvolvidas.

\section{PROCEDIMENTOS METODOLÓGICOS}

Neste trabalho optou-se por uma pesquisa do tipo exploratória, com um viés descritivo com o objetivo de se obter uma visão geral, do fenômeno. É o tipo de pesquisa mais adequado aos temas que foram pouco explorados e sob os quais há certa dificuldade em se construir hipóteses sobre ele de forma mais específica.

Com relação à abordagem, optou-se pela quantitativa, uma vez que o intuito principal é a verificar se existe correspondência entre os resultados obtidos por intermédio da análise de duas medidas de competitividade distintas: aquela que é percebida pelos gestores e a que pode ser medida efetivamente por meio de indicadores de desempenho da destinação.

Em termos de estratégia de pesquisa, o autor escolheu a realização de um estudo multicasos, por meio do qual, buscava performance of certain indicator in that way. For a better understanding of the indicators used, they were divided into separate sets, adapted from the studies of Esser et al. (1996): macro environment and micro environment. The first set, related to the macro environment, directly involves all the developments related to the tourism sector in a particular country; however, they are perceived differently by the managers, to the extent that there are variations in local laws. The second set is subdivided into four other subgroups (attractions, infrastructure, competition and competitive management) whose construction was drawn from the model of Dwyer and Kim (2003), - complemented by the studies of Porter (1989), Esser et al. (1996), Heat (2002) and Ritchie and Crouch (2003) - that attempts to present the trend in relation to the competitive performance of a particular tourist destination.

In this article, all indicators were considered as equally important, analogous to what is proposed in the systems theory, developed by Bertallanffy (1967). Thus, to evaluate the level of competitiveness it was found, according to the responses of managers, the number of indicators identified as competitive (those whose average score was between 4 and 6). Then they classified into three groups according to the number of indicators considered as competitive, similar to what was done in the studies of Mazaro and Varzin (2008):

- Up to 12 indicators - low competitiveness - tend to achieve lower performance than the average of the state;

- Over 12 and up to 24 indicators average competitiveness - tend to achieve similar performance to the average of the state; and

- Over 24 indicators - high competitiveness - tend to achieve higher performance than the average of the state.

The chosen variables and indicators for verification of real competitive performance of a tourist destination, shown in Table 2, had as theoretical basis the studies by Dwyer and Kim (2003). These indicators allow a direct comparison, through the use of concrete and measurable data, provided by official agencies of research or that can be obtained through field research, to collect primary data (Table 2 ). 
encontrar evidências que de acordo com os estudos desenvolvidos por Yin (2010) pudessem conduzir à confirmação dos aspectos específicos que determinam a ocorrência do fenômeno.

Para alcançar os objetivos propostos Dencker (2001) afirma que devem ser escolhidas variáveis, com base no referencial teórico e que possam auxiliar na identificação de quais são as características mais importantes do fenômeno que serve como foco central do estudo.

O quadro 1 mostra o conjunto de variáveis utilizado para auxiliar na análise da percepção dos gestores em relação ao desempenho competitivo de seus destinos turísticos quando confrontados com a média do desempenho turístico auferido para o Estado de Santa Catarina. Vianna (2011) utilizou como referencial teórico para a construção desse conjunto de variáveis e indicadores os trabalhos de Porter (1989), Esser et ali (1996), Heat (2002), Ritchie e Crouch (2003), Dwyer e Kim (2003) e Blanke, Chiesa e Herrera (2009). Posteriormente todo o conjunto foi revisado, discutido e ampliado por meio de reuniões feitas pelo grupo de estudos sobre Planejamento e Gestão de Espaços Turísticos da UNIVALI (Universidade do Vale do Itajaí) (Quadro 01).

Optou-se pela escolha de indicadores mais amplos que possibilitassem o aprofundamento posterior por meio de estudos específicos que visassem explicar de maneira detalhada os motivos que levaram os gestores a perceber o desempenho de determinado indicador daquela forma. Para melhor compreensão dos indicadores utilizados, os mesmos foram divididos em conjuntos distintos, adaptados a partir dos estudos de Esser et ali (1996): macro ambiente e micro ambiente. O primeiro conjunto ligado ao macro ambiente envolve diretamente todos os empreendimentos ligados à área de turismo em um determinado país, contudo, são percebidos de maneira diferente pelos gestores, na medida em que ocorrem variações nas legislações locais. O segundo conjunto é subdividido em outros quatro subgrupos (atrativos, infra-estrutura, concorrência e gestão competitiva) cuja construção foi elaborada a partir do modelo de Dwyer e Kim (2003), complementado pelos estudos de Porter (1989), Esser et ali (1996), Heat (2002) e Ritchie e Crouch (2003) e que tenta apresentar qual seria a tendência em relação ao desempenho competitivo de uma determinada destinação turística.
Like in the classification of performance perceived by managers, the criteria used by Mazaro and Varzin (2008) in their research were adopted here. They divided the final classification into three groups of competitive performance (high, medium and low). To determine the score to be assigned to each indicator the following criteria were established: 5 points for indicators with performance above the standard; 2.5 points for indicators with performance close to the set pattern; and 1 point for the indicators with performance below the set standard. The final classification is made according to the following criteria:

- Up to 21 points - low competitive performance;

- Over 21 and up to 43 points average competitive performance; and

- Above 43 points high competitive performance.

The criterion for selecting the municipalities was having, at current prices, a gross value added in services representing more than $50 \%$ of total GDP (Gross Domestic Product) at current prices; thus showing the dependence of this sector. After identifying these municipalities, a new selection criterion was applied: chose the ones whose percentage of the estimated income from tourism, in relation to gross value added in services, represents at least $50 \%$ of this, which demonstrates the strength of the activity in the municipality.

Data for the estimated tourism revenue was obtained from Santur (2008) - the body responsible for monitoring tourism in the state of Santa Catarina - and refer to only two months (January and February - high season). Based on the established criteria, the municipalities of Santa Catarina selected for the multi case study were: Camboriú, Bombinhas and Garopaba.

For the analysis of the perception of competitiveness of the selected tourist destinations, managers were selected from the hotels and inns registered in ABIH (Brazilian Hotel Industry Association), representing the lodging industry and the managers of bars and restaurants registered in the ABRASEL (Brazilian Association of Bars and Restaurants), association representing the eating and drinking places industry. Due to the small number of establishments affiliated to the institutions mentioned we also used an alternative source of research: the "Guia 
Neste artigo todos os indicadores foram considerados como igualmente importantes, de modo análogo ao que propõe a teoria sistêmica, elaborada por Bertalanffy (1967). Desta forma, para avaliar qual era o nível de competitividade apurou-se, de acordo com as respostas dos gestores, quantos indicadores foram apontados como competitivos (aqueles cuja média da pontuação ficou entre 4 e 6). Em seguida procedeu-se a uma classificação dividida em três grupos, conforme a quantidade de indicadores considerados como competitivos, de modo similar ao que foi feito nos estudos de Mazaro e Varzin (2008):

- Até 12 indicadores - baixa competitividade - tendência a alcançar desempenho inferior à média do estado;

- Acima de 12 e até 24 indicadores média competitividade - tendência a alcançar desempenho similar à média do estado; e

- Acima de 24 indicadores - alta competitividade - tendência a alcançar desempenho superior à média do estado.

As variáveis e indicadores escolhidos para a verificação do desempenho competitivo real de uma destinação turística, mostrados no quadro 2 , tiveram como base teórica os estudos de Dwyer e Kim (2003). Tais indicadores possibilitam sua comparação direta, por meio da utilização de dados concretos e mensuráveis, disponibilizados pelos órgãos oficiais de pesquisa ou que podem ser obtidos por meio de pesquisa de campo, ao levantar dados primários (Quadro 2).

Da mesma maneira como se procedeu na classificação do desempenho percebido pelos gestores, aqui também se adotou os mesmos critérios utilizados por Mazaro e Varzin (2008) em sua pesquisa, que optaram por dividir a classificação final em três grupos de desempenho competitivo (alto, médio e baixo). Para determinar a pontuação a ser atribuída a cada indicador optou-se pelo seguinte critério: 5 pontos para indicadores com desempenho acima do padrão; 2,5 pontos para indicadores com desempenho próximo do padrão definido; e 1 ponto para os indicadores com desempenho abaixo do padrão definido. A classificação final será feita obedecendo ao seguinte critério:

- Até 21 pontos - baixo desempenho competitivo;
Quatro Rodas Brazil - GQR" in its 2011 version (GQR, 2011).

Complementing the universe of managers, there were also public administrators and managers of supporting tourist activities. The former are responsible for the definition of policies and guidelines for the development of tourism in their region and the latter are in charge of support organizations established in each of the municipalities in question.

For an organization to have higher performance than another, it is necessary to define standards that allow the comparison, as proposed by authors such as Ghemawat (2000), Mintzberg, Ahlstrand and Lampel (2000), Omerzel (2008) and Kunst (2009). In this article the average of the indicators was chosen as a basis of comparison; the indicators were analyzed in the tourist destinations surveyed by Santur, in 2008 (Balneário Camboriú, Blumenau, Bombinhas, Florianópolis, Fraiburgo, Garopaba, Itajaí, Jaraguá do Sul, Joinville, Laguna Penha, Pomerode, Porto Belo, São Franscisco do Sul, São Joaquim and Urubici) ([Table 3).

The values defined as the average performance of tourist destinations analyzed are shown in Table 3. Part of the indicators was built on the basis of information provided by Santur (collected during the high season, which includes the months of January and February of the year 2008). For example, the indicator "Foreign tourists" refers to the expected amount of domestic and foreign tourists and the associated percentage was calculated regarding each municipality, and then the mean was obtained as it is shown in the table.

The indicator associated to "Employed Population" was calculated by determining the percentage of total employed persons (IBGE, 2010 ) in relation to the total population of each municipality, extracting the simple arithmetic mean value expressed in Table 3. Similarly, to obtain the number of "Candidates per Job Vacancy ", it was found the total number of inhabitants, which was divided by the number of companies in the city (IBGE, 2010) and then the arithmetic mean was calculated, becoming the reference value. The other indicators were based on secondary sources of information, whose means were calculated for the set of the cities studied.

Some indicators did not have information that could be cleared through secondary indicators, e.g., the indicator "volume of 
- Acima de 21 e até 43 pontos médio desempenho competitivo; e

- Acima de 43 pontos alto desempenho competitivo.

O critério adotado para a seleção dos municípios a serem pesquisados foi o de que o município possuísse em seu valor adicionado bruto de serviços a preços correntes um montante que representasse mais de $50 \%$ do total do PIB (Produto Interno Bruto) a preços correntes, o que demonstraria a dependência deste setor. Após a identificação dos municípios que se enquadram neste critério, adotou-se novo critério de seleção que escolheu àqueles cujo percentual da renda estimada do turismo, em relação ao valor adicionado bruto de serviços representasse no mínimo $50 \%$ desse valor, o que demonstraria a força da atividade neste município.

O valor relativo à receita estimada do turismo foi obtido junto à Santur (2008) órgão responsável pelo monitoramento da atividade turística no Estado de Santa Catarina - e refere-se a apenas dois meses (janeiro e fevereiro - meses de alta temporada). Com base nos critérios estabelecidos, foram selecionados para o estudo multicaso, os municípios catarinenses de Balneário Camboriú, Bombinhas e Garopaba.

Foram selecionados, para a análise da percepção da competitividade dos destinos turísticos selecionados, os gestores dos hotéis e pousadas cadastrados na ABIH (Associação Brasileira da Indústria Hoteleira), entidade responsável pela representação do setor de hospedagem e os gestores responsáveis pelos bares e restaurantes cadastrados junto à ABRASEL (Associação Brasileira de Bares e Restaurantes) organização responsável pelo setor gastronômico. Em razão da pequena quantidade de estabelecimentos filiados às instituições citadas optou-se pela utilização de uma fonte de pesquisa alternativa que é o "Guia Quatro Rodas Brasil - GQR" em sua versão 2011 (GQR, 2011).

Complementando o universo de gestores junto aos quais será avaliada a percepção da competitividade foram escolhidos os gestores públicos responsáveis pela definição de políticas e diretrizes voltadas ao desenvolvimento do turismo em suas respectivas destinações turísticas e ainda os gestores das organizações encarregadas pelo apoio e suporte que se encontram fisicamente estabelecidas em cada uma dos municípios em análise. investments made". Thus, it was opted for using $3 \%$ of reinvestment (to be calculated on the value of Estimated Revenue of Tourism) as a standard value. The authors have considered this a sufficient amount for the established enterprises (public or private) to maintain and upkeep the existing tourist structures. The 3\% value was reached choosing as a parameter the inflation target set for the year 2011 (which was $4.5 \%$ ), which means that two thirds of this amount is sufficient to ensure quality in terms of structure.

Another indicator whose standard was defined by the researchers was the "Investor Satisfaction". In this case it was adopted the principle that an investor to maintain, and even expand, the interest in a certain field of activity, has to obtain a minimum of $80 \%$ satisfaction with the enterprise, since this performance can be considered at least as a good investment.

\section{DATA ANALYSIS}

The objective indicators of competitiveness, selected from the studies of Dwyer and Kim (2003) allowed to verify the correspondence between the performance of each of the municipalities chosen as the basis for this study and the average performance determined by the group of municipalities chosen by Santur (2008) as the basis for research, since they all allowed quantification and comparison.

Noting the matching between managers' perceptions of competitiveness and the actual performance of municipalities is possible to verify that such a perception can be used as a tool (for those responsible for setting investment policy) to determine priority in the allocation of resources based on factual information; and to enable a more appropriate way to choose where the funds will be used. It is observed that the priorities were defined by reference to the set of strengths and weaknesses diagnosed by managers of established businesses and which can contribute to increase the competitive performance of their destination, just as it was verified by Heath (2002) studies.

A point that deserves to be highlighted about the indicators to determine the competitiveness is the fact that the authors kept focused on covering most aspects present in the definition of competitiveness, adopted as the basis for the present study. Therefore, it encompasses the tourists' satisfaction 
Para que uma organização tenha desempenho maior que outra, faz-se necessário a definição de padrões que permitam a comparação, tal como é proposto por autores como Ghemawat (2000), Mintzberg, Ahlstrand e Lampel (2000), Omerzel (2008) e Kunst (2009). No presente artigo se escolheu como base de comparação a média dos indicadores analisados junto às demais destinações turísticas pesquisadas pela Santur, no ano de 2008 (Balneário Camboriú, Blumenau, Bombinhas, Florianópolis, Fraiburgo, Garopaba, Itajaí, Jaraguá do Sul, Joinville, Laguna, Penha, Pomerode, Porto Belo, São Franscisco do Sul, São Joaquim e Urubici). (Quadro 3).

Os valores apurados como sendo o desempenho médio das destinações turísticas analisadas são apresentados no quadro 3 . Parte dos indicadores foi construída com base nas informações disponibilizadas pela Santur (coletadas durante o período de alta temporada, que compreende aos meses de janeiro e fevereiro do ano de 2008). Como exemplo cita-se o indicador "Turistas Estrangeiros", cujas informações referem-se à quantidade prevista de turistas nacionais e estrangeiros e dos quais foi calculado o valor percentual associado a cada município, sendo em seguida obtida a média que foi demonstrada no quadro.

$O$ indicador associado à "População Empregada" foi calculado por meio da apuração do percentual do total de pessoas empregadas (IBGE, 2010) em relação ao total da população de cada município, dos quais foi extraída a média aritmética simples, valor expresso no quadro 3. Da mesma forma, para se obter o número de "Candidatos por Vaga de Emprego", apurou-se o número total de habitantes, o qual foi dividido pelo número de empresas existentes no município (IBGE, 2010), para em seguida calcular a média aritmética, que foi considerada como sendo o valor de referência. Os demais indicadores, tiveram com base fontes secundárias de informação, das quais foram calculadas as médias referentes ao conjunto de municípios estudados.

Alguns indicadores não possuíam informações que pudessem ser apuradas por meio de indicadores secundários, como é a situação do indicador "Volume de investimentos feitos". Assim, optou-se por utilizar como valor padrão um percentual de reinvestimento de $3 \%$ (a ser calculado sobre - valor da Receita Estimada do Turismo), regarding the stay at the destination, the volume of spending by tourists, the offered jobs to the community and the satisfaction of investors with the project, which is not always analyzed by other authors who have studied the subject as Porter (1989), Heath (2002) and Blanke, Chiesa and Herrera (2009).

The first tourist destination to be evaluated was Balneário Camboriú, where it was found that most of the selected indicators to measure the real competitiveness presented a performance above the average of the state. When a destination achieves overall performance that surpasses 52 points, it is considered a highly competitive performance, as defined by the authors and based on studies of Marzaro and Varzin (2008). The complete picture about the indicators used in each of the surveyed tourist destinations can be checked by analyzing the data in Vianna's (2011) study. The score coincides with the vision of managers who have considered the perceived performance as high, which shows the relationship between the results, as proposed by the authors. However, this result could have been caused by mere coincidence, given that it was based on a single observation of the phenomenon in question.

Regarding the municipality of Bombinhas it was found, through data on effective competitive performance, that there was a slight predominance of the indicators that showed an above average performance. However, there was a significant set of indicators on which the performance was below the average of the state, culminating in a general score of 42.5 points. This score, according to the parameters defined in the methodology of the study, leads to the understanding that effective competitive performance is considered average, which corresponds to the performance perceived by managers of existing enterprises in this destination, made in an earlier analysis. In this case, Heath (2002), Dwyer and Kim (2003), Ritchie and Crouch (2003) and Vianna's (2011) assumption that the perception of managers would get the same assessment that the real competitiveness is, once more, confirmed. In order to consider that this was a phenomenon's behavior pattern we draw on the principle by Yin (2010), which states that a third check should be carried out to ensure the triangulation in relation to the observation of reality.

The third tourist destination analyzed was the city of Garopaba. In this case there was a balance between the set of indicators that have achieved results above the average of 
uma vez que os autores consideram que este seja um montante suficiente para que os empreendimentos estabelecidos (públicos ou privados) façam a manutenção e conservação das estruturas existentes que sejam voltadas ao atendimento dos turistas. Para chegar ao percentual de $3 \%$ escolheu-se utilizar como parâmetro a meta de inflação estipulada para o ano de 2011 (que era de 4,5\%) da qual entende-se que 2/3 (dois terços) desse valor seja suficiente para garantir o padrão de qualidade existente em termos de estrutura.

Outro indicador cujo padrão foi definido pelos pesquisadores foi 0 relativo à "Satisfação dos Investidores". Neste caso adotou-se o princípio de que para um investidor manter e até mesmo ampliar o interesse em determinado ramo de atividade, é imprescindível que obtenha no mínimo $80 \%$ de satisfação com seu empreendimento, uma vez que tal desempenho pode ser considerado como no mínimo um bom investimento.

\section{ANÁLISE DOS DADOS}

Os indicadores objetivos de competitividade, selecionados a partir dos estudos de Dwyer e Kim (2003) permitiram a verificação da correspondência entre o desempenho de cada um dos municípios escolhidos como base para este estudo e a média de desempenho apurado junto ao conjunto de municípios escolhido pela Santur (2008) como base para pesquisa, uma vez que todos permitiam sua exata quantificação e comparação.

Ao constatar-se a existência da correspondência entre a percepção dos gestores em relação à competitividade e o desempenho real dos municípios é possível verificar que tal percepção dos gestores pode ser utilizada como ferramenta (por parte dos responsáveis pela definição de políticas de investimento) para determinar a prioridade na alocação de recursos com base em informações concretas e que viabilizem uma forma mais adequada de escolher onde deverão ser aplicados os recursos. Observa-se que as prioridades foram definidas tomando por referência o conjunto de pontos fortes e pontos fracos diagnosticados pelos gestores dos empreendimentos estabelecidos e que podem contribuir para o aumento do desempenho competitivo de sua destinação, da mesma maneira como pode ser verificado pelos estudos de Heath (2002). the state and one whose performance was below. Thus, this municipality scored a total of 40 points, which led it to be regarded as having an average performance in terms of real competitiveness. With this score, Garopaba had the lower performance among all municipalities surveyed. However, the goal was not to classify the destinations in relation to its actual competitive performance so, the actual results were only compared with the managers' perception. Again, there was a match between the perceptions of the managers of established enterprises and the effective results. Therefore, it is possible to conclude that this is not just another coincidence and can thus be seen as a pattern of behavior that may be associated with this phenomenon (Figure 1).

Figure 1 shows that in the three cases investigated there is an evident match between the results assessing the managers' perceptions and the effective competitive performance, measured in each of the studied tourist destinations. In the municipality of Balneário Camboriú (BC) the competitive performance was considered high $(\mathrm{H})$ by the managers of the enterprises involved, and the actual performance was also considered high according to the established standards of comparison. In the municipalities of Bombinhas (Bo) and Garopaba (Ga) it was found that managers perceived competitiveness as having average performance $(A)$ and the assessment of real competitiveness demonstrates the same result, which reinforces the results of research made by Crouch and Ritchie (2003) and Dwyer and Kim (2003). Neither of the studied destinations had low (L) competitiveness score.

The above results, reinforced by Yin's (2010) studies, permit the conclusion that there is a match between the perceptions of managers of tourism enterprises established, with respect to competitive performance, and actual competitive results obtained in each municipality studied, which allows public authorities to use this information as a source of assistance in defining investment priorities in tourism.

\section{FINAL CONSIDERATIONS}

This study aimed to analyze the correspondence between the perception of tourism managers regarding the competitiveness of their municipalities and 
Um ponto relativo à composição do quadro de indicadores efetivos para apuração da competitividade que merecer ser destacado refere-se ao fato de que os autores tiveram a preocupação de manterem-se focados em abranger a maioria dos aspectos presentes na definição de competitividade adotada como base para o presente estudo, pois, envolve desde a satisfação dos turistas com a estadia no destino, o volume de gastos dos turistas, a oferta de empregos para a comunidade e até a satisfação dos investidores com o empreendimento, o que nem sempre é considerado por outros autores que já estudaram o assunto como Porter (1989), Heath (2002) e Blanke, Chiesa e Herrera (2009).

A primeira destinação turística a ser avaliada é Balneário Camboriú, onde se apurou que a maioria dos indicadores selecionados para medir a competitividade real apresentou desempenho considerado acima da média do estado, uma vez que no computo geral, quando uma destinação alcança desempenho global que supera o montante de 52 pontos, considera-se como desempenho competitivo alto, de acordo com a definição feita pelos autores, baseados nos estudos de Marzaro e Varzin (2008). O quadro completo com os indicadores utilizados em cada uma das destinações turísticas pesquisadas pode ser conferido por meio da análise dos dados feita no estudo de Vianna (2011). Tal constatação coincide com a visão dos gestores que haviam considerado o desempenho percebido como alto, o que demonstra a correspondência entre os resultados apurados, tal como proposto pelos autores. Porém, tal resultado poderia ter sido originado por mera coincidência, haja vista que se baseava em uma única observação do fenômeno em análise.

Em relação ao município de Bombinhas constatou-se, por meio da apuração dos dados referentes ao desempenho competitivo efetivo, que houve uma pequena predominância dos indicadores que indicavam um desempenho acima da média. Porém, houve um conjunto expressivo de indicadores nos quais o desempenho foi abaixo da média do estado, culminando numa pontuação geral que alcançou 42,5 pontos. Tal pontuação, conforme parâmetros definidos na metodologia do estudo, leva ao entendimento de que o desempenho competitivo efetivo seja considerado médio, o que corresponde ao desempenho percebido pelos gestores dos empreendimentos existentes nesta destinação quando da análise feita anteriormente. the real competitive performance of these. To achieve this goal a survey was conducted in the municipalities of Santa Catarina in which tourism is the main economic activity. The theoretical basis was built from the review of concepts related to the definition of tourist destination and competitiveness, in order to provide readers with a new perspective on these two constructs and thus facilitating their ascertainment through research tools less complex and more familiar to the managers involved.

The research instrument used as conceptual basis the studies of Porter (1989), Esser et al. (1996), Heath (2002), Crouch and Ritchie (2003), Dwyer and Kim (2003) and Vianna (2011) and sought to analyze the perception of managers and was considered by them as appropriate. In addition, it enabled the researchers to go beyond the strictly quantitative view provided by the stratification of results in terms of high, medium or low performance; also, it allowed to identify the indicators with worse performance scores, and thus encouraging the adoption of measures to improve the situation, further, it motivates the commitment of those involved in the continuous improvement of procedures and actions considered positive.

The study led the authors to conclude that this type of tool simplifies data collection on competitive performance of a destination, as it does not require that respondents spend a lot of time to answer the survey instruments. This fact allows the frequent application of such instruments, and thus providing regular monitoring of results, giving the managers useful data on whether or not actions taken are achieving the desired results or if there is a need for adjustments.

Another important conclusion of this study refers to the fact that the analysis carried out highlights the strengths and the weaknesses of the development of tourism in each of the surveyed destinations; and demonstrates that the managers' perception in relation to competitiveness of their municipalities is consistent with the actual performance achieved through objective indicators of competitiveness.

Regarding the selected set of indicators for the assessment of effective competitive performance of tourist destinations, based on the studies of Dwyer and Kim (2003) and Vianna (2011), one can conclude that it shows various aspects that contribute to verify the 
Neste caso confirmam-se novamente os pressupostos existentes nas pesquisas de Heath (2002), Dwyer e Kim (2003), Ricthie e Crouch (2003) e Vianna (2011), de que a percepção dos gestores obteria a mesma avaliação que a competitividade real. Mas, para que fosse possível considerar que esse era um padrão para o comportamento deste fenômeno, seguiu-se o princípio proposto por Yin (2009), no qual deveria ser realizada uma terceira verificação com o intuito de garantir a triangulação em relação à observação da realidade.

A terceira destinação turística analisada foi o município de Garopaba. Neste caso evidenciou-se o equilíbrio entre o conjunto de indicadores que alcançaram resultados acima da média do estado e aquele cujo desempenho ficou abaixo da média do estado. Essa situação fez com que neste município fosse verificado um escore total de 40 pontos, o que o levou a ser considerado como tendo um desempenho médio em termos de competitividade real. Constatou-se que com este escore, Garopaba foi o que menor desempenho alcançou entre todos os municípios pesquisados. Porém, como o objetivo não incluía a construção de uma classificação de destinações em relação à seu desempenho competitivo efetivo, apenas procedeu-se à comparação dos resultados reais com a percepção dos gestores. Mais uma vez, constatou-se a existência de correspondência entre a percepção dos gestores dos empreendimentos estabelecidos e o resultado da apuração efetiva, sendo, portanto, possível chegar à conclusão de que essa não é um apenas uma coincidência isolada, podendo se considerar que este seja um padrão de comportamento que pode ser associado a este fenômeno (Figura 1).

Por meio da figura 1 é possível constatar que nos três casos investigados ficou evidenciada a correspondência entre os resultados que avaliaram tanto a percepção dos gestores, quanto o desempenho competitivo efetivo mensurado em cada uma das destinações turísticas estudadas. No município de Balneário Camboriú (BC) verificou-se que o desempenho competitivo foi considerado alto (A) pelos gestores dos empreendimentos envolvidos, enquanto o desempenho real também foi considerado alto em função dos padrões de comparação estabelecidos. Já nos municípios de Bombinhas (Bo) e Garopaba (Ga) verificou-se que os gestores percebem a competitividade como tendo médio desempenho (M) e a avaliação competitive potential of a municipality, as it encompasses aspects beyond the purely economic factors, demonstrating other dimensions that can be associated with community development in a broader sense.

In the three cases examined, there was a match between the perception of managers and the actual competitive results of the tourist destinations, confirming the main purpose of this article, that is, the managers' perception of competiveness matches the real performance measured by means of selected indicators. Thus, it creates the possibility that public policies and actions are defined using the surveys with the managers of established enterprises, putting in evidence the aspects that need improvement in order to expand the competitive potential of the tourist destination.

Finally, the authors point out that the creation of a joint agenda involving all the stakeholders (public authorities, private companies and community) tends to strengthen the dialogue and the relation between the involved, as proposed by the studies of Esser et al. (1996). This connection would result in greater efficiency in investments to be made by the tourism sector, so that existing resources are able to achieve better results, as it would serve to meet both the interests of entrepreneurs seeking better financial outcome and the community in general, seeking to improve the quality of life.

As a suggestion for future research the authors refer the need for further studies on this topic, deepening the importance of using this type of tool to monitor the competitive potential of tourist destinations, enabling the constant improvement of their projects and the correct allocation of public resources involved.

\section{REFERENCES}

BARNEY, J. (1991) Firm recourses and sustained competitive advantage. Journal of Management, Vol. 17, no 1, p. 99-120.

BERTALLANFFY, L. (1975) Teoria geral dos sistemas. Petrópolis: Vozes.

BLANKE, J.; CHIESA, T. (2009) The travel \& tourism competitiveness report 2009. WEF - WORLD ECONOMIC FORUM. Genebra.

BLANKE, J.; CHIESA, T.; HERRERA, E. T. (2009) The travel \& tourism competitiveness index 2009: measuring sectoral drivers in a downturn. In: BLANKE, J.; CHIESA, T. (2009) The 
da competitividade real demonstra o mesmo resultado, o que reforça os resultados das pesquisas de Crouch e Ritchie (2003) e Dwyer e Kim (2003).

Os resultados acima expostos, reforçados pelas afirmações oriundas dos estudos de Yin (2009), permitem que se conclua de que há correspondência entre a percepção dos gestores dos empreendimentos turísticos estabelecidos com relação ao desempenho competitivo e os resultados competitivos efetivos apurados jem cada um dos municípios estudados, o que permite ao poder público a utilização destas informações como fonte de subsídios para definição de prioridades de investimentos na área de turismo.

\section{CONSIDERAÇÕES FINAIS}

O presente estudo teve como objetivo principal a análise da correspondência entre percepção dos gestores ligados à área de turismo de uma destinação turística em relação à competitividade de seus municípios e o real desempenho competitivo dos mesmos. Para alcançar este objetivo foi realizada uma pesquisa junto aos municípios catarinenses nos quais o turismo aparece como sendo a principal atividade econômica. A base teórica para o desenvolvimento do artigo foi construída a partir da revisão dos conceitos relativos à definição de destinação turística e de competitividade, visando proporcionar aos leitores uma nova visão sobre estes dois constructos, de maneira a viabilizar sua apuração por intermédio de instrumentos de pesquisa menos complexos e mais familiares aos gestores envolvidos.

$O$ instrumento de pesquisa desenvolvido utilizou como base conceitual os estudos de Porter (1989), Esser et ali (1996), Heath (2002), Crouch e Ritchie (2003), Dwyer e Kim (2003) e Vianna (2011) e voltou-se para a análise da percepção dos gestores, tendo sido considerado por estes como apropriado. Além disso, possibilitou que os pesquisadores fossem além da visão estritamente quantitativa proporcionada pela estratificação do resultado em termos de desempenho alto, médio ou baixo, permitindo a verificação de quais foram os indicadores cuja avaliação teve o pior desempenho, com o intuito de incentivar que sejam adotadas medidas para melhorar essa situação, além de motivar o empenho dos envolvidos na melhoria contínua dos procedimentos e ações que obtiveram avaliações que possam ser consideradas como positivas. travel \& tourism competitiveness report 2009. WEF - WORLD ECONOMIC FORUM. Genebra, pp. 3-39.

BUHALIS, D. (2000) Marketing the competitive destination of the future. Tourism Management. Vol. 21, pp. 97-116.

CROUCH, G. I.; RITCHIE, J. R. B. (1995) Destination competitiveness and the role of the tourism enterprise. Unpublished Woking Paper WP 95-19, may.

CROUCH, G. I.; RITCHIE, J. R. B.(1999) Tourism, competitiveness, and social prosperity. Journal of Business Research. Vol. 44, pp. 137-152.

CROUCH, G. I. (2007) Measuring tourism competitiveness: research, theory and WEF índex. In: AUSTRALIAN AND NEW ZEALAND MARKETING ACADEMY (ANZMAC) CONFERENCE 2007, [Annals...] Nova Zelândia, 3-5/dec. Retrieved from: <http://conferences.anzmac.org/ ANZMAC2007/papers/Crouch_1.pdf> Accessed: april. 24th 2010.

DENCKER, A. F. M. (2001) Pesquisa em turismo - planejamento, métodos e técnicas. São Paulo: Futura.

DWYER, L.; KIM, C. (2003) Destination competitiveness: determinants and indicators. Current Issues in Tourism. Vol. 6, No 5, pp. 369-414.

ESSER, K.; HILLEBRAND, W.; MESSNER, D.; MEYER-STAMER, J. (1996) Systemic Competitiveness - New governance patterns for industrial development. Londres: First Class. Available at: <http:// www.meyer-stamer.de/1996/sysco-book. pdf> Accessed: april, 20 th 2010.

GHEMAWAT, P. (2000) A estratégia e o cenário dos negócios - textos e casos. Porto Alegre: Bookman.

GQR - Guia Quatro Rodas. (2011) Brasil 2011. São Paulo: Abril.

HEATH, E. (2002) Towards a model to enhance Africa's sustainable tourism competitiveness. Jornal of Public Administration. Vol. 37, No 3.1 , pp. 327353, nov.

IBGE - Instituto Brasileiro de Geografia e Estatística. (2010) Cadastro central de empresas 2008. Rio de Janeiro: IBGE. Available at: <http://www.ibge.gov.br/ cidadesat/topwindow.htm?1> Accessed: may, $20^{\text {th }}, 2011$.

KIM, C.; DWYER, L. (2003) Destination competitiviness and bilateral tourism flows between Australia and Korea. The Journal of Tourism Studies. Vol. 14, No 2, pp. 5567.

KUNST, I. (2009) Tourist destination competitiveness assessment - approach 
O estudo levou os autores a concluir que este tipo de ferramenta agiliza a coleta de informações relativas ao desempenho competitivo de uma destinação, pois não requer que os respondentes venham a despender grande quantidade de tempo para responder aos instrumentos de pesquisa, fato este que permitiria a replicação da aplicação de tais instrumentos com uma freqüência determinada, visando proporcionar acompanhamento regular dos resultados, o que possibilitaria aos gestores envolvidos verificar se as ações implementadas estão obtendo os resultados desejados ou se há a necessidade de que sejam realizados novos ajustes.

Outra conclusão importante que este estudo viabilizou refere-se ao fato de que a análise realizada possibilitou que fossem verificados os pontos fortes e os pontos fracos relativos ao desenvolvimento da atividade turística em cada um dos destinos pesquisados e demonstrou que a percepção dos gestores em relação a capacidade competitiva de seus municípios está condizente com o real desempenho verificado por meio de indicadores concretos de competitividade.

Em relação ao conjunto de indicadores selecionados para a avaliação do desempenho competitivo efetivo das destinações turísticas, que teve como referencial teórico os estudos de Dwyer e Kim (2003) e Vianna (2011), pode-se concluir que o mesmo mostra vários aspectos que contribuem para a verificação do potencial competitivo de um município, uma vez que engloba aspectos que não restringemse aos fatores meramente econômicos, demonstrando outros aspectos que podem ser associados ao desenvolvimento da comunidade num sentido mais amplo.

Nos três casos avaliados foi possível constatar a correspondência entre a percepção dos gestores e os resultados competitivos reais das destinações turísticas investigadas, o que permitiu que o objetivo principal deste artigo fosse alcançado, pois confirmou-se que a percepção dos gestores em relação à competitividade corresponde ao desempenho real mensurado por meio dos indicadores selecionados. Desta maneira cria-se a possibilidade de que sejam definidas políticas públicas e ações que se utilizem dos levantamentos feitos junto aos gestores dos empreendimentos estabelecidos, os quais demonstram com maior quantidade de detalhes em que pontos ainda há a necessidade de melhoras visando contribuir and limitations. Acta Turistica. Vol. 21, No 2, pp.123-159.

MAZARO, R. M.; VARZIN, G. (2008) Modelos de competitividad para destinos turísticos em el marco de la sostenibilidad. Revista de Administração Contemporânea. Vol. 12, No 3.

MINTZBERG, H.; AHLSTRAND, B.; JOSEPH,L. (2000) Safári de Estratégia. Porto Alegre: Bookman.

MOTA, K. C. N.; VIANNA, S. L. G.; ANJOS, F. A. (2013) Competitividade das destinações turísticas - estudos de casos brasileiros. São Paulo: Atlas.

NEWALL, J. E. (1992) The challenge of competitiveness. Business Quarterly, Vol. 56 , No 4.

OMT - Organização Mundial do Turismo. (2001) Introdução ao turismo. São Paulo: Roca.

OMERZEL, D. G.; MIHALIC, T. (2008) Destination competitiveness - applying different models, the case of Slovenia. Tourism Management. Vol. 29, pp. 294307.

PETERAF, M. A. (1993) The cornerstones of competitive advantage: a resource-based view. Strategic Management Journal. Vol. 14, pp. 179-191.

PORTER, M. E. (1986) Estratégia Competitiva - técnicas para análise de indústrias e da concorrência. $7^{\text {a }}$.ed. Rio de Janeiro: Campus.

PORTER, M. E. (1989) A vantagem competitiva das nações. Rio de Janeiro: Campus.

RITCHIE, J. R. B.; CROUCH, G. I. (2003) The competitive destination - a sustainable tourism perspective. Estados Unidos: CAB International.

SANTUR - Santa Catarina Turismo S/A. (2008) Pesquisa mercadológica estudo da demanda turística. Pesquisa de demanda turística. Demanda Turística 2008. Available at: <http://www.santur.sc.gov.br/index.php? option=com_docman\&task=cat_view \&gid=45\&Itemid=215> Accessed: jun, $18^{\text {th }}, 2011$.

TEECE, D. J.; PISANO, G.; SHUEN, A. (1997) Dynamic capabilities and strategic management. Strategic Management Journal. Vol. 18, No 7, pp. 509-533.

TSAI, H.; SONG, H.; WONG, K. K. F. (2009) Tourism and hotel competitiveness research. Journal of Travel \& Tourism Marketing. Vol. 26, No 5\&6, pp. 522-546, jul.

WERNERFELT, B. (1984) A recource-based view of the firm. Strategic Management Journal. Vol. 5, pp. 171-180.

WTTC - World Travel \& Tourism Council. 
para a ampliação do potencial competitivo da destinação turística.

Por fim os autores destacam que a criação de uma agenda conjunta de ações que envolva as diversas entidades ligadas ao poder público, o conjunto de empreendimentos controlados pela iniciativa privada e a comunidade de uma forma geral tende a contribuir para o fortalecimento do diálogo e da articulação entre os envolvidos, tal como proposto pelos estudos de Esser et ali (1996). Tal tipo de articulação viria a resultar em maior eficiência nos investimentos a serem feitos pelo setor de turismo, de modo que os recursos existentes consigam atingir melhores resultados, uma vez que serviriam para atender aos interesses tanto dos empreendedores que buscam melhor resultado financeiro, quanto da comunidade em geral que busca a melhoria da qualidade de vida.

Como sugestão para futuras pesquisas os autores apontam para a necessidade de novos estudos relativos à este tema, que venham a aprofundar a importância do uso deste tipo de ferramenta para o monitoramento do potencial competitivo das destinações turísticas de maneira a viabilizar o constante aprimoramento de seus empreendimentos e a correta destinação dos recursos públicos envolvidos.

\section{REFERÊNCIAS}

BARNEY, J. (1991) Firm recources and sustained competitive advantage. Journal of Management, Vol. 17, no 1, p. 99-120.

BERTALLANFFY, L. (1975) Teoria geral dos sistemas. Petrópolis: Vozes.

BLANKE, J.; CHIESA, T. (2009) The travel \& tourism competitiveness report 2009. WEF - WORLD ECONOMIC FORUM. Genebra.

BLANKE, J.; CHIESA, T.; HERRERA, E. T. (2009) The travel \& tourism competitiveness index 2009: measuring sectoral drivers in a downturn. In: BLANKE, J.; CHIESA, T. (2009) The travel \& tourism competitiveness report 2009. WEF WORLD ECONOMIC FORUM. Genebra, pp. 3-39.

BUHALIS, D. (2000) Marketing the competitive destination of the future. Tourism Management. Vol. 21, pp. 97-116.

CROUCH, G. I.; RITCHIE, J. R. B. (1995) Destination competitiveness and the role of the tourism enterprise. Unpublished Woking Paper WP 95-19, may.

CROUCH, G. I.; RITCHIE, J. R. B.(1999)
(2009) Viagens \& Turismo: impacto econômico - Santa Catarina. London: WTTC - World Travel \& Tourism Council. Available at: <http://www.wttc.org/bin/ pdf/original_pdf.../sc_report_portuguese_ low_res.pdf > Accessed: april, 18 ${ }^{\text {th }}, 2011$. YIN, R. K. (2010) Estudo de caso: planejamento e métodos. $4^{\mathrm{a}}$ ed., Porto Alegre: Bookman. 
Tourism, competitiveness, and social prosperity. Journal of Business Research. Vol. 44, pp. 137-152.

CROUCH, G. I. (2007) Measuring tourism competitiveness: research, theory and WEF índex. In: AUSTRALIAN AND NEW ZEALAND MARKETING ACADEMY (ANZMAC) CONFERENCE 2007, [Annals...] Nova Zelândia, 3-5/dec. Available at: <http://conferences.anzmac.org/ ANZMAC2007/papers/Crouch_1.pdf > Accessed: april. 24 $4^{\text {th }}, 2010$.

DENCKER, A. F. M. (2001) Pesquisa em turismo - planejamento, métodos e técnicas. São Paulo: Futura.

DWYER, L.; KIM, C. (2003) Destination competitiveness: determinants and indicators. Current Issues in Tourism. Vol. 6, No 5, pp. 369-414.

ESSER, K.; HILLEBRAND, W.; MESSNER, D.; MEYER-STAMER, J. (1996) Systemic Competitiveness - New governance patterns for industrial development. Londres: First Class. Available at: <http:// www.meyer-stamer.de/1996/sysco-book. pdf> Accessed: april, 20 2010.

GHEMAWAT, P. (2000) A estratégia e o cenário dos negócios - textos e casos. Porto Alegre: Bookman.

GQR - Guia Quatro Rodas. (2011) Brasil 2011. São Paulo: Abril.

HEATH, E. (2002) Towards a model to enhance Africa's sustainable tourism competitiveness. Jornal of Public Administration. Vol. 37, No 3.1, pp. 327353, nov.

IBGE - Instituto Brasileiro de Geografia e Estatística. (2010) Cadastro central de empresas 2008. Rio de Janeiro: IBGE. Available at: <http://www.ibge.gov.br/ cidadesat/topwindow.htm?1> Accessed: may, 20th 2011.

KIM, C.; DWYER, L. (2003) Destination competitiviness and bilateral tourism flows between Australia and Korea. The Journal of Tourism Studies. Vol. 14, No 2, pp. 5567.

KUNST, I. (2009) Tourist destination competitiveness assessment - approach and limitations. Acta Turistica. Vol. 21, No 2, pp.123-159.

MAZARO, R. M.; VARZIN, G. (2008) Modelos de competitividad para destinos turísticos em el marco de la sostenibilidad. Revista de Administração Contemporânea. Vol. 12, No 3.

MINTZBERG, H.; AHLSTRAND, B.; JOSEPH,L. (2000) Safári de Estratégia. Porto Alegre: Bookman.

MOTA, K. C. N.; VIANNA, S. L. G.; ANJOS, F.
A. (2013) Competitividade das destinações turísticas - estudos de casos brasileiros. São Paulo: Atlas.

NEWALL, J. E. (1992) The challenge of competitiveness. Business Quarterly, Vol. 56 , No 4.

OMT - Organização Mundial do Turismo. (2001) Introdução ao turismo. São Paulo: Roca.

OMERZEL, D. G.; MIHALIC, T. (2008) Destination competitiveness - applying different models, the case of Slovenia. Tourism Management. Vol. 29, pp. 294307.

PETERAF, M. A. (1993) The cornerstones of competitive advantage: a resource-based view. Strategic Management Journal. Vol. 14, pp. 179-191.

PORTER, M. E. (1986) Estratégia Competitiva - técnicas para análise de indústrias e da concorrência. 7a.ed. Rio de Janeiro: Campus.

PORTER, M. E. (1989) A vantagem competitiva das nações. Rio de Janeiro: Campus.

RITCHIE, J. R. B.; CROUCH, G. I. (2003) The competitive destination - a sustainable tourism perspective. Estados Unidos: CAB International.

SANTUR - Santa Catarina Turismo S/A. (2008) Pesquisa mercadológica estudo da demanda turística. Pesquisa de demanda turística. Demanda Turística 2008. Available at: <http://www.santur.sc.gov.br/index.php? option=com_docman\&task=cat_view \&gid=45\&Itemid=215> Accessed: jun, $18^{\text {th }}, 2011$.

TEECE, D. J.; PISANO, G.; SHUEN, A. (1997) Dynamic capabilities and strategic management. Strategic Management Journal. Vol. 18, No 7, pp. 509-533.

TSAI, H.; SONG, H.; WONG, K. K. F. (2009) Tourism and hotel competitiveness research. Journal of Travel \& Tourism Marketing. Vol. 26, No 5\&6, pp. 522-546, jul.

WERNERFELT, B. (1984) A recource-based view of the firm. Strategic Management Journal. Vol. 5, pp. 171-180.

WTTC - World Travel \& Tourism Council. (2009) Viagens \& Turismo: impacto econômico Santa Catarina. London: WTTC - World Travel \& Tourism Council. Available at: <http://www.wttc.org/bin/pdf/original_ pdf.../sc_report_portuguese_low_res.pdf $>$ Accessed: april, 18 ${ }^{\text {th }}, 2011$.

YIN, R. K. (2010) Estudo de caso: planejamento e métodos. $4^{a}$ ed., Porto Alegre: Bookman. 


\section{Attachments}

Quadro 1 - Variáveis e Indicadores para análise da percepção dos gestores quanto à competitividade

\begin{tabular}{|c|c|c|}
\hline & Objetivo & Base Teórica \\
\hline \multicolumn{3}{|l|}{ Macro Ambiente } \\
\hline Índice de Inflação & \begin{tabular}{|c|} 
Verificar se os componentes macroeconômicos \\
contribuem para o desempenho competitivo
\end{tabular} & \multirow{2}{*}{$\begin{array}{l}\text { Esser et ali (1996); Dwyer } \\
\text { e Kim (2003) }\end{array}$} \\
\hline Taxa de Câmbio & $\begin{array}{c}\text { Verificar se política cambial contribui para o } \\
\text { desempenho competitivo }\end{array}$ & \\
\hline $\begin{array}{l}\text { Exigências para obtenção de Visto } \\
\text { de Entrada }\end{array}$ & $\begin{array}{c}\text { Verificar se a política de relações exteriores } \\
\text { contribui para o desempenho competitivo }\end{array}$ & $\begin{array}{c}\text { Dwyer e Kim (2003); Kim } \\
\text { e Dwyer (2003) }\end{array}$ \\
\hline $\begin{array}{l}\text { Políticas Nacionais de Preservação } \\
\text { Ambiental }\end{array}$ & $\begin{array}{l}\text { Verificar a contribuição delas para o } \\
\text { desempenho competitivo }\end{array}$ & \multirow{2}{*}{$\begin{array}{l}\text { Heat }(2002) \text {; Ritchie e } \\
\quad \text { Crouch (2003) }\end{array}$} \\
\hline $\begin{array}{l}\text { Políticas Nacionais de } \\
\text { Desenvolvimento do Turismo }\end{array}$ & $\begin{array}{l}\text { Verificar a contribuição delas para o } \\
\text { desempenho competitivo }\end{array}$ & \\
\hline $\begin{array}{l}\text { Organizações de Suporte e Apoio } \\
\text { ao Turismo em Âmbito Nacional }\end{array}$ & $\begin{array}{c}\text { Verificar a contribuição da atuação delas para } \\
\text { o desempenho competitivo }\end{array}$ & \begin{tabular}{|c|} 
Porter (1989); Esser et \\
ali (1996); Dwyer e Kim \\
$(2003)$
\end{tabular} \\
\hline \multicolumn{3}{|l|}{ Micro Ambiente } \\
\hline \multicolumn{3}{|l|}{ Atrativos } \\
\hline Naturais & $\begin{array}{l}\text { Verificar se belezas naturais, fauna e flora } \\
\text { contribuem para o desempenho competitivo }\end{array}$ & \multirow{5}{*}{$\begin{array}{l}\text { Dwyer e Kim (2003); } \\
\text { Ritchie e Crouch (2003); } \\
\quad \text { Kim e Dwyer(2003) }\end{array}$} \\
\hline Culturais & \begin{tabular}{|c|} 
Verificar se os museus, monumentos, \\
bibliotecas, parques de exposição contribuem \\
para o desempenho competitivo
\end{tabular} & \\
\hline Entretenimento & $\begin{array}{l}\text { Verificar se os cinemas, teatros, boates, } \\
\text { parques temáticos e parques ecológicos } \\
\text { contribuem para o desempenho competitivo }\end{array}$ & \\
\hline Compras & $\begin{array}{c}\text { Verificar se os shopping centers, centros de } \\
\text { compra, lojas de artesanato contribuem para } \\
\text { o desempenho competitivo }\end{array}$ & \\
\hline Eventos & \begin{tabular}{|c|}
$\begin{array}{c}\text { Verificar se as festas típicas, apresentações } \\
\text { de grupos folclóricos e feiras contribuem para } \\
\text { o desempenho competitivo }\end{array}$ \\
\end{tabular} & \\
\hline \multicolumn{3}{|l|}{ Infra Estrutura } \\
\hline Acomodações & $\begin{array}{l}\text { Verificar se a estrutura de hospedagem da } \\
\text { rede de hotéis e pousadas contribui para o } \\
\text { desempenho competitivo }\end{array}$ & \multirow{6}{*}{$\begin{array}{l}\text { Dwyer e Kim (2003); } \\
\text { Ritchie e Crouch (2003); } \\
\text { Kim e Dwyer (2003) }\end{array}$} \\
\hline Gastronomia & \begin{tabular}{|c|}
$\begin{array}{c}\text { Verificar se a estrutura de restaurantes, bares } \\
\text { e lanchonetes contribui para o desempenho } \\
\text { competitivo }\end{array}$ \\
\end{tabular} & \\
\hline Acessibilidade & $\begin{array}{l}\text { Verificar se as condições das estradas } \\
\text { de acesso ao destino contribuem para o } \\
\text { desempenho competitivo }\end{array}$ & \\
\hline Comunicação & $\begin{array}{c}\text { Verificar se as placas de sinalização para que } \\
\text { o turista se orientar pelo destino contribuem } \\
\text { para o desempenho competitivo }\end{array}$ & \\
\hline Saneamento & \begin{tabular}{|c|}
$\begin{array}{c}\text { Verificar se as condições de abastecimento de } \\
\text { água e a coleta de esgotos contribuem para o } \\
\text { desempenho competitivo }\end{array}$ \\
\end{tabular} & \\
\hline Conveniência & $\begin{array}{c}\text { Verificar se a estrutura de acesso a bens de } \\
\text { consumo e itens relativos às necessidades } \\
\text { básicas contribui para o desempenho } \\
\text { competitivo }\end{array}$ & \\
\hline Segurança & \begin{tabular}{|c|}
$\begin{array}{c}\text { Verificar a perspectiva de garantia da } \\
\text { segurança física e patrimonial contribui para o } \\
\text { desempenho competitivo }\end{array}$ \\
\end{tabular} & \multirow{2}{*}{$\begin{array}{l}\text { Dwyer e Kim (2003); } \\
\text { Ritchie e Crouch (2003); } \\
\text { Kim e Dwyer (2003) }\end{array}$} \\
\hline Saúde & $\begin{array}{c}\text { Verificar se a estrutura de atendimento } \\
\text { básico à saúde contribui para o desempenho } \\
\text { competitivo }\end{array}$ & \\
\hline
\end{tabular}




\begin{tabular}{|c|c|c|}
\hline \multicolumn{3}{|l|}{ Concorrência } \\
\hline Oferta & $\begin{array}{c}\text { Verificar se a quantidade de estabelecimentos } \\
\text { que oferecem serviços aos turistas (número } \\
\text { de hotéis } x \text { número de restaurantes) contribui } \\
\text { para o desempenho competitivo }\end{array}$ & \multirow{4}{*}{$\begin{array}{l}\text { Dwyer e Kim (2003); } \\
\text { Ritchie e Crouch (2003) }\end{array}$} \\
\hline Demanda & $\begin{array}{l}\text { Verificar se a quantidade de turistas que } \\
\text { demandam por serviços contribui para o } \\
\text { desempenho competitivo }\end{array}$ & \\
\hline Fornecedores & $\begin{array}{c}\text { Verificar se as empresas encarregadas } \\
\text { de suprir as necessidades das empresas } \\
\text { instaladas contribui para o desempenho } \\
\text { competitivo }\end{array}$ & \\
\hline Hospitalidade & $\begin{array}{c}\text { Verificar se a receptividade dos residentes } \\
\text { em relação aos turistas contribui para o } \\
\text { desempenho competitivo }\end{array}$ & \\
\hline Recursos Humanos & $\begin{array}{c}\text { Verificar se a qualificação dos recursos } \\
\text { humanos utilizados no atendimento ao turista } \\
\text { contribui para o desempenho competitivo }\end{array}$ & $\begin{array}{c}\text { Heat (2002); Dwyer e Kim } \\
\text { (2003) Ritchie e Crouch } \\
(2003)\end{array}$ \\
\hline $\begin{array}{l}\text { Instituições de Pesquisa e } \\
\text { Desenvolvimento }\end{array}$ & $\begin{array}{c}\text { Verificar se a atuação das instituições de } \\
\text { pesquisa e desenvolvimento contribui para o } \\
\text { desempenho competitivo }\end{array}$ & $\begin{array}{c}\text { Esser et ali (1996); Dwyer } \\
\text { e Kim (2003) }\end{array}$ \\
\hline $\begin{array}{l}\text { Políticas Locais/Regionais de } \\
\text { Proteção Ambiental }\end{array}$ & $\begin{array}{c}\text { Verificar a contribuição delas para o } \\
\text { desempenho competitivo }\end{array}$ & \multirow{2}{*}{$\begin{array}{l}\text { Heat (2002); Ritchie e } \\
\text { Crouch (2003) }\end{array}$} \\
\hline \begin{tabular}{|l|} 
Políticas Locais/Regionais de \\
Desenvolvimento do Turismo
\end{tabular} & $\begin{array}{l}\text { Verificar a contribuição delas para o } \\
\text { desempenho competitivo }\end{array}$ & \\
\hline $\begin{array}{l}\text { Organizações de Apoio e Suporte } \\
\text { em Âmbito Local/Regional }\end{array}$ & $\begin{array}{c}\text { Verificar a contribuição da atuação delas para } \\
\text { o desempenho competitivo }\end{array}$ & $\begin{array}{c}\text { Esser et ali (1996); Dwyer } \\
\text { e Kim (2003) }\end{array}$ \\
\hline \multicolumn{3}{|l|}{ Gestão Competitiva } \\
\hline Gestão de Marketing & $\begin{array}{c}\text { Verificar se a divulgação e a publicidade } \\
\text { do destino contribuem para o desempenho } \\
\text { competitivo }\end{array}$ & \multirow{2}{*}{$\begin{array}{l}\text { Dwyer e Kim (2003); } \\
\text { Ritchie e Crouch (2003) }\end{array}$} \\
\hline Gestão Ambiental & $\begin{array}{c}\text { Verificar se a preservação e sustentabilidade } \\
\text { dos recursos naturais contribuem para o } \\
\text { desempenho competitivo }\end{array}$ & \\
\hline Gestão Tecnológica & $\begin{array}{c}\text { Verificar se o desenvolvimento de sistemas } \\
\text { informatizados contribui para o desempenho } \\
\text { competitivo }\end{array}$ & \multirow{6}{*}{$\begin{array}{c}\text { Dwyer e Kim (2003); } \\
\text { Ritchie e Crouch (2003) }\end{array}$} \\
\hline Gestão de Recursos Humanos & \begin{tabular}{|c|} 
Verificar se a qualificação e o \\
acompanhamento das necessidades de \\
mão-de-obra contribuem para o desempenho \\
competitivo
\end{tabular} & \\
\hline Gestão da Oferta & $\begin{array}{c}\text { Verificar se a análise da capacidade instalada } \\
\text { contribui para o desempenho competitivo }\end{array}$ & \\
\hline Gestão da Demanda & $\begin{array}{l}\text { Verificar se a análise do fluxo de turistas } \\
\text { contribui para o desempenho competitivo }\end{array}$ & \\
\hline Gestão do Conhecimento & $\begin{array}{l}\text { Verificar se a disseminação de práticas } \\
\text { de sucesso entre as empresas instaladas } \\
\text { contribui para o desempenho competitivo }\end{array}$ & \\
\hline $\begin{array}{l}\text { Monitoramento e Avaliação da } \\
\text { Competitividade }\end{array}$ & $\begin{array}{c}\text { Verificar se o processo utilizado contribui para } \\
\text { o desempenho competitivo }\end{array}$ & \\
\hline
\end{tabular}

Fonte: Vianna (2011, p.148-151). 
Table 1 - Variables and indicators to analyze the managers' perception of competitiveness

\begin{tabular}{|c|c|c|}
\hline Indicator & Goal & Theoretical Basis \\
\hline \multicolumn{3}{|l|}{ Macro Environment } \\
\hline Inflation Index & $\begin{array}{l}\text { Check if the macroeconomic components } \\
\text { contribute to the competitive performance }\end{array}$ & \multirow{2}{*}{$\begin{array}{l}\text { Esser et al. (1996); Dwyer } \\
\text { and Kim (2003) }\end{array}$} \\
\hline Exchange Rate & $\begin{array}{c}\text { Check if the exchange rate policy contributes } \\
\text { to the competitive performance }\end{array}$ & \\
\hline $\begin{array}{l}\text { Requirements for obtaining Entry } \\
\text { Visa }\end{array}$ & $\begin{array}{l}\text { Check if the foreign relations policy } \\
\text { contributes to the competitive performance }\end{array}$ & $\begin{array}{l}\text { Dwyer and Kim (2003); } \\
\text { Kim and Dwyer (2003) }\end{array}$ \\
\hline $\begin{array}{l}\text { National Environmental } \\
\text { Preservation Policies (NEPP) }\end{array}$ & $\begin{array}{l}\text { Check if the NEPP contribute to the } \\
\text { competitive performance }\end{array}$ & \multirow{2}{*}{$\begin{array}{l}\text { Heat (2002); Ritchie and } \\
\quad \text { Crouch (2003) }\end{array}$} \\
\hline \begin{tabular}{|l|} 
National Policies of Tourism \\
Development (NPTD) \\
\end{tabular} & $\begin{array}{l}\text { Check if the NPTD contribute to the } \\
\text { competitive performance }\end{array}$ & \\
\hline $\begin{array}{l}\text { Supporting Organizations and } \\
\text { Support Tourism at a National } \\
\text { Level }\end{array}$ & $\begin{array}{c}\text { Check if they contribute to the competitive } \\
\text { performance }\end{array}$ & \begin{tabular}{|c|}
$\begin{array}{c}\text { Porter (1989); Esser et al. } \\
(1996) ; \\
\text { Dwyer and Kim } \\
(2003)\end{array}$ \\
\end{tabular} \\
\hline \multicolumn{3}{|l|}{ Micro Environment } \\
\hline \multicolumn{3}{|l|}{ Attractive } \\
\hline Natural & $\begin{array}{l}\text { Check if natural beauty, flora and fauna } \\
\text { contribute to the competitive performance }\end{array}$ & \multirow{5}{*}{$\begin{array}{l}\text { Dwyer and Kim (2003); } \\
\text { Ritchie and Crouch (2003); } \\
\text { Kim and Dwyer(2003) }\end{array}$} \\
\hline Cultural & $\begin{array}{l}\text { Check if the museums, monuments, libraries, } \\
\text { exhibition parks contribute to the competitive } \\
\text { performance }\end{array}$ & \\
\hline Entertainment & $\begin{array}{c}\text { Check if cinemas, theaters, nightclubs, theme } \\
\text { parks and ecological parks contribute to the } \\
\text { competitive performance }\end{array}$ & \\
\hline Shopping & $\begin{array}{c}\text { Check if the malls, shopping centers, } \\
\text { craft shops contribute to the competitive } \\
\text { performance }\end{array}$ & \\
\hline Events & \begin{tabular}{|c|}
$\begin{array}{c}\text { Check if the traditional festivals, presentations } \\
\text { of folk groups and fairs contribute to the } \\
\text { competitive performance }\end{array}$ \\
\end{tabular} & \\
\hline \multicolumn{3}{|l|}{ Infrastructure } \\
\hline Accommodation & $\begin{array}{l}\text { Check if the lodging network contributes to } \\
\text { the competitive performance }\end{array}$ & \multirow{6}{*}{$\begin{array}{l}\text { Dwyer and Kim (2003); } \\
\text { Ritchie and Crouch } \\
\text { (2003); Kim and Dwyer } \\
\text { (2003) }\end{array}$} \\
\hline Gastronomy & $\begin{array}{c}\text { Check if the structure of restaurants, bars } \\
\text { and snack bars contributes to the competitive } \\
\text { performance }\end{array}$ & \\
\hline Accessibility & $\begin{array}{c}\text { Check if the conditions of the destination } \\
\text { access roads contribute to the competitive } \\
\text { performance }\end{array}$ & \\
\hline Communication & $\begin{array}{c}\text { Check if the signposts for guiding tourists in } \\
\text { the destination contribute to the competitive } \\
\text { performance }\end{array}$ & \\
\hline Sanitation & $\begin{array}{c}\text { Check if the water supply conditions and } \\
\text { the sewage collection contribute to the } \\
\text { competitive performance }\end{array}$ & \\
\hline Convenience & $\begin{array}{l}\text { Check if structure of access to consumer } \\
\text { goods and items relating to basic needs } \\
\text { contributes to the competitive performance }\end{array}$ & \\
\hline
\end{tabular}




\begin{tabular}{|c|c|c|}
\hline Security & $\begin{array}{l}\text { Check if safety and security prospect } \\
\text { contributes to the competitive performance }\end{array}$ & $\begin{array}{l}\text { Dwyer and Kim (2003); } \\
\text { Ritchie and Crouch } \\
\text { (2003); Kim and Dwyer } \\
(2003)\end{array}$ \\
\hline Health & $\begin{array}{l}\text { Check if the primary health care structure } \\
\text { contributes to the competitive performance }\end{array}$ & \\
\hline \multicolumn{3}{|l|}{ Competition } \\
\hline Offer & $\begin{array}{c}\text { Check if the amount of establishments } \\
\text { offering services to tourists (number of hotels } \\
\text { and number of restaurants) contributes to the } \\
\text { competitive performance }\end{array}$ & \multirow{4}{*}{$\begin{array}{c}\text { Dwyer and Kim (2003); } \\
\text { Ritchie and Crouch (2003) }\end{array}$} \\
\hline Demand & $\begin{array}{c}\text { Check if the amount of tourists that demand } \\
\text { for services contributes to the competitive } \\
\text { performance }\end{array}$ & \\
\hline Providers & $\begin{array}{c}\text { Check if the providers of the established } \\
\text { companies contribute to the competitive } \\
\text { performance }\end{array}$ & \\
\hline Hospitality & $\begin{array}{c}\text { Check if the receptivity of residents in relation } \\
\text { to tourists contributes to the competitive } \\
\text { performance }\end{array}$ & \\
\hline Human Resources & $\begin{array}{c}\text { Check if qualification of the human resources } \\
\text { dealing with tourists contributes to the } \\
\text { competitive performance }\end{array}$ & $\begin{array}{l}\text { Heat (2002); Dwyer and } \\
\text { Kim (2003) Ritchie and } \\
\text { Crouch (2003) }\end{array}$ \\
\hline $\begin{array}{l}\text { Research and Development } \\
\text { Institutions }\end{array}$ & $\begin{array}{l}\text { Check if the performance of research and } \\
\text { development institutions contributes to the } \\
\text { competitive performance }\end{array}$ & $\begin{array}{l}\text { Esser et al. (1996); Dwyer } \\
\quad \text { and Kim (2003) }\end{array}$ \\
\hline \begin{tabular}{|l|} 
Local Policies / Regional \\
Environmental Protection (LPEP)
\end{tabular} & $\begin{array}{l}\text { Check if LPEP contribute to the competitive } \\
\text { performance }\end{array}$ & \multirow{2}{*}{$\begin{array}{l}\text { Heat }(2002) ; \text { Ritchie and } \\
\text { Crouch (2003) }\end{array}$} \\
\hline $\begin{array}{l}\text { Local Policies / Tourism Regional } \\
\text { Development (LPTD) }\end{array}$ & $\begin{array}{c}\text { Check if LPTD contribute to the competitive } \\
\text { performance }\end{array}$ & \\
\hline \begin{tabular}{|l|} 
Supporting Organizations and \\
Support in Scope Local / Regional
\end{tabular} & $\begin{array}{l}\text { Check if their performance contributes to the } \\
\text { competitive performance }\end{array}$ & $\begin{array}{l}\text { Esser et al. (1996); Dwyer } \\
\text { and Kim (2003) }\end{array}$ \\
\hline \multicolumn{3}{|l|}{ Competitive Management } \\
\hline Marketing Management & $\begin{array}{c}\text { Check if promoting and advertising the } \\
\text { destination contribute to the competitive } \\
\text { performance }\end{array}$ & \multirow{2}{*}{$\begin{array}{c}\text { Dwyer and Kim (2003); } \\
\text { Ritchie and Crouch (2003) }\end{array}$} \\
\hline Environmental Management & $\begin{array}{l}\text { Check if preservation and sustainability } \\
\text { of natural resources contribute to the } \\
\text { competitive performance }\end{array}$ & \\
\hline Technology Management & $\begin{array}{c}\text { Check if development of computerized } \\
\text { systems contributes to the competitive } \\
\text { performance }\end{array}$ & \multirow{6}{*}{ Ditchie and Crouch (2003) } \\
\hline Human Resources Management & $\begin{array}{c}\text { Check if the qualification and monitoring of } \\
\text { workforce needs contribute to the competitive } \\
\text { performance }\end{array}$ & \\
\hline Supply Management & $\begin{array}{l}\text { Check if the analysis of the installed capacity } \\
\text { contributes to the competitive performance }\end{array}$ & \\
\hline Demand Management & $\begin{array}{l}\text { Check if the analysis of the flow of tourists } \\
\text { contribute to the competitive performance }\end{array}$ & \\
\hline Knowledge Management & \begin{tabular}{|c|} 
Check if the dissemination of successful \\
practices among companies contributes to the \\
competitive performance
\end{tabular} & \\
\hline $\begin{array}{l}\text { Monitoring and Evaluation of } \\
\text { Competitiveness }\end{array}$ & $\begin{array}{l}\text { Check if the process used to monitoring } \\
\text { contributes to the competitive performance }\end{array}$ & \\
\hline
\end{tabular}


Quadro 2 - Indicadores de desempenho competitivo real

\begin{tabular}{|c|c|}
\hline Indicador & Descrição \\
\hline Turistas estrangeiros & $\begin{array}{l}\text { Valor referente ao percentual do número de turistas } \\
\text { estrangeiros em relação ao total de turistas previsto }\end{array}$ \\
\hline Receita Estimada do Turismo Total & $\begin{array}{c}\text { Valor em R\$ (reais) estimado a ser arrecadado pelo turismo } \\
\text { no destino }\end{array}$ \\
\hline Taxa de ocupação da rede hoteleira & Valor referente ao percentual de ocupação da rede hoteleira \\
\hline $\begin{array}{l}\text { Média de gastos dos turistas nacionais por } \\
\text { dia }\end{array}$ & $\begin{array}{l}\text { Valor em R\$(reais) referente ao gasto médio dos turistas } \\
\text { nacionais por dia }\end{array}$ \\
\hline $\begin{array}{l}\text { Média de gastos dos turistas estrangeiros } \\
\text { por dia }\end{array}$ & $\begin{array}{c}\text { Valor em R\$ (reais) referente ao gasto médio dos turistas } \\
\text { estrangeiros por dia }\end{array}$ \\
\hline $\begin{array}{l}\text { Média de tempo de permanência em hotéis } \\
\text { no destino }\end{array}$ & $\begin{array}{l}\begin{array}{l}\text { Número médio de dias de permanência dos turistas no } \\
\text { destino }\end{array} \\
\end{array}$ \\
\hline Procura por meios de hospedagem & $\begin{array}{l}\text { Valor percentual referente à quantidade de turistas que } \\
\text { procuram por hospedagem em hotéis e pousadas }\end{array}$ \\
\hline Receita estimada do turismo por habitante & $\begin{array}{c}\text { Valor estimado de receita do turismo em } \mathrm{R} \$ \text { (reais) dividido } \\
\text { pelo número de habitantes }\end{array}$ \\
\hline Renda Média Mensal & $\begin{array}{l}\text { Número médio de salários mínimos recebidos pelos residentes } \\
\text { no destino }\end{array}$ \\
\hline Volume de investimentos feitos & $\begin{array}{c}\text { Montante de investimentos feitos no setor conforme } \\
\text { levantamento de campo realizado }\end{array}$ \\
\hline População empregada & $\begin{array}{l}\text { Valor percentual referente ao quociente entre o total de } \\
\text { pessoas empregadas em relação ao número de habitantes }\end{array}$ \\
\hline Candidatos por vagas de emprego & $\begin{array}{l}\text { Número de habitantes dividido pelo total de empresas } \\
\text { atuantes cadastradas }\end{array}$ \\
\hline $\begin{array}{r}\text { Satisfação com o investimento } \\
\text { Fonte: Adaptaçã }\end{array}$ & $\begin{array}{c}\text { Valor percentual referente à satisfação dos gestores com } \\
\text { o investimento feito em seus empreendimentos, conforme } \\
\text { levantamento de campo } \\
\text { a partir dos estudos de Dwyer e Kim (2003) }\end{array}$ \\
\hline
\end{tabular}

Table 2 - Real competitive performance indicators

\begin{tabular}{|c|c|}
\hline Indicator & Description \\
\hline Foreign Tourists & $\begin{array}{l}\text { Percentage of foreign tourists in relation to the total tourists } \\
\text { estimated }\end{array}$ \\
\hline Estimated Revenue Total Tourism & $\begin{array}{c}\text { Value in } \mathrm{R} \$ \text { (Real) estimated to be raised by tourism in } \\
\text { destination }\end{array}$ \\
\hline Hotel Occupancy Rate & Percentage of lodging industry occupancy \\
\hline Domestic Tourism Average Daily Spend & $\begin{array}{c}\text { Value in } \mathrm{R} \$ \text { (real) for the average spending of domestic } \\
\text { tourists per day }\end{array}$ \\
\hline Foreign Tourists Average Daily Spend & $\begin{array}{c}\text { Value in R\$ (real) for the average spending of foreign tourists } \\
\text { per day }\end{array}$ \\
\hline Hotel Average Length of Stay & Average number of days of stay of tourists in the destination \\
\hline Demand for Lodging Facilities & $\begin{array}{c}\text { Percentage of tourists looking for accommodation in hotels } \\
\text { and inns }\end{array}$ \\
\hline Estimated Per Capita Revenue of Tourism & $\begin{array}{c}\text { Estimated tourism revenue in } \mathrm{R} \$ \text { (real) divided by number of } \\
\text { inhabitants }\end{array}$ \\
\hline Average Monthly Income & $\begin{array}{l}\text { Average number of minimum wages received by residents in } \\
\text { destination }\end{array}$ \\
\hline Volume of Investments Made & $\begin{array}{l}\text { Amount of investment made in the sector according to field } \\
\text { survey }\end{array}$ \\
\hline Employed Population & $\begin{array}{l}\text { Percentage of people employed in relation to the number of } \\
\text { inhabitants }\end{array}$ \\
\hline Candidates per Job Vacancy & $\begin{array}{c}\text { Number of inhabitants divided by total active companies } \\
\text { registered }\end{array}$ \\
\hline Satisfaction with the Investment & $\begin{array}{c}\text { Percentage of satisfaction of managers regarding the } \\
\text { investment made in their businesses, according to field } \\
\text { survey }\end{array}$ \\
\hline
\end{tabular}


Quadro 3 - Padrão de referência para análise dos indicadores efetivos de competitividade

\begin{tabular}{|c|c|c|}
\hline Competitividade & Desempenho Médio & Origem \\
\hline Turistas estrangeiros & $13,39 \%$ & Santur \\
\hline Receita estimada do turismo & $\mathrm{R} \$ 121.123 .229,84$ & Santur \\
\hline $\begin{array}{l}\text { Taxa de ocupação da rede } \\
\text { hoteleira }\end{array}$ & $58,54 \%$ & Santur \\
\hline $\begin{array}{l}\text { Média de gastos dos turistas } \\
\text { nacionais por dia }\end{array}$ & $\mathrm{R} \$ 59,36$ & Santur \\
\hline $\begin{array}{l}\text { Média de gastos dos turistas } \\
\text { estrangeiros por dia }\end{array}$ & $\mathrm{R} \$ 60,01$ & Santur \\
\hline $\begin{array}{l}\text { Média de tempo de permanência } \\
\text { em hotéis no destino }\end{array}$ & 3,20 dias & Santur \\
\hline $\begin{array}{l}\text { Procura por meios de } \\
\text { hospedagem }\end{array}$ & $40,08 \%$ & Santur \\
\hline $\begin{array}{l}\text { Receita estimada do turismo por } \\
\text { habitante }\end{array}$ & $\mathrm{R} \$ 65,45$ & Santur \\
\hline Renda média mensal & 2,7 & IBGE \\
\hline População empregada & $33,93 \%$ & IBGE \\
\hline Candidatos por vaga de emprego & 23,368 & IBGE \\
\hline Volume de investimentos feitos & $R \$ 3.633 .696,90$ & \multirow{2}{*}{$\begin{array}{c}\text { Padrão definido pelo } \\
\text { Pesquisador }\end{array}$} \\
\hline Satisfação com o investimento & $80,00 \%$ & \\
\hline
\end{tabular}

Table 3 - Reference standard for analysis of the effective competitiveness indicators

\begin{tabular}{|l|c|c|}
\hline Competitiveness & Average Performance & Source \\
\hline Foreign Tourists & $13.39 \%$ & Santur \\
\hline Estimated Revenue Total Tourism & R $\$ 121,123,229.84$ & Santur \\
\hline Hotel Occupancy Rate & $58.54 \%$ & Santur \\
\hline $\begin{array}{l}\text { Domestic Tourism Average Daily } \\
\text { Spend }\end{array}$ & R $\$ 59.36$ & Santur \\
\hline $\begin{array}{l}\text { Foreign Tourists Average Daily } \\
\text { Spend }\end{array}$ & R $\$ 60.01$ & Santur \\
\hline Hotel Average Length of Stay & 3.20 dias & Santur \\
\hline Demand for Lodging Facilities & $40.08 \%$ & Santur \\
\hline Estimated Per Capita Revenue of \\
Tourism
\end{tabular}




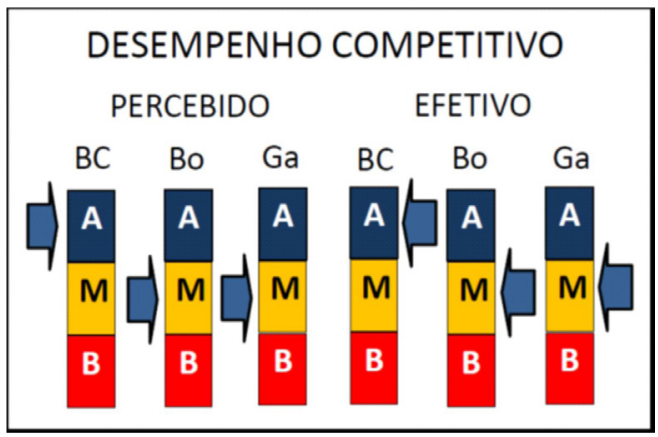

Figura 1 - Verificação quanto à correspondência percebida entre os constructos. Fonte: Elaboração dos autores (2015).

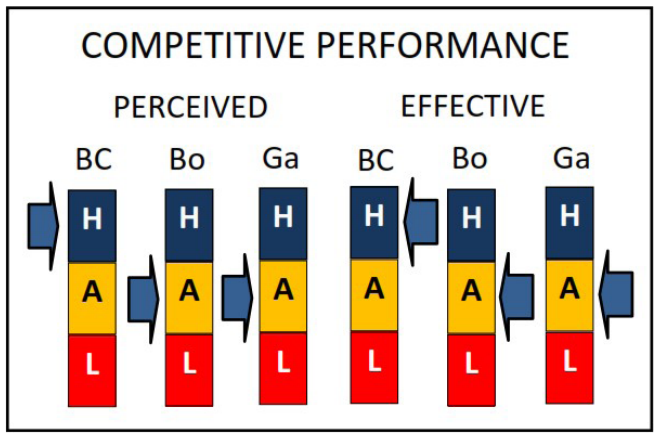

Figure 1 - Checking for correspondence perceived between the constructs. Source: Prepared by the Authors (2015). 